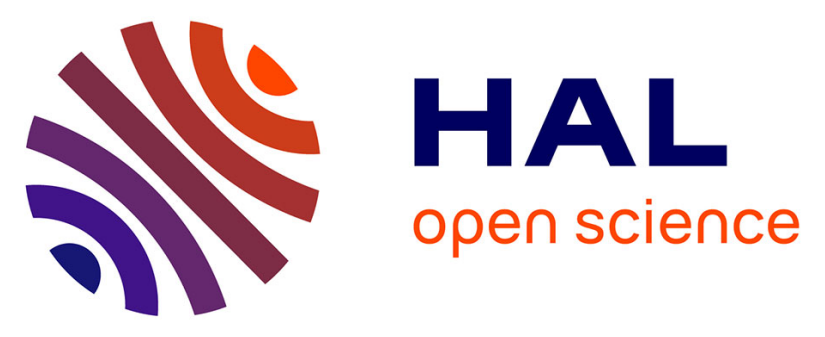

\title{
Characterizing the regional contribution to PM10 pollution over northern France using two complementary approaches: Chemistry transport and trajectory-based receptor models
}

Elise Potier, Antoine Waked, A. Bourin, Fanny Minvielle, Jean-Christophe Péré, Esperanza Perdrix, Vincent Michoud, V. Riffault, L.Y. Alleman, S. Sauvage

\section{- To cite this version:}

Elise Potier, Antoine Waked, A. Bourin, Fanny Minvielle, Jean-Christophe Péré, et al.. Characterizing the regional contribution to PM10 pollution over northern France using two complementary approaches: Chemistry transport and trajectory-based receptor models. Atmospheric Research, 2019, 223, pp.1-14. 10.1016/j.atmosres.2019.03.002 . hal-02552748

\author{
HAL Id: hal-02552748 \\ https://hal.science/hal-02552748
}

Submitted on 22 Oct 2021

HAL is a multi-disciplinary open access archive for the deposit and dissemination of scientific research documents, whether they are published or not. The documents may come from teaching and research institutions in France or abroad, or from public or private research centers.
L'archive ouverte pluridisciplinaire HAL, est destinée au dépôt et à la diffusion de documents scientifiques de niveau recherche, publiés ou non, émanant des établissements d'enseignement et de recherche français ou étrangers, des laboratoires publics ou privés.

\section{(ㄷ)(1) $\$$}

Distributed under a Creative Commons Attribution - NonCommerciall 4.0 International 


\title{
Characterizing the regional contribution to $\mathrm{PM}_{10}$ pollution over
}

\author{
northern France using two complementary approaches:
}

\section{Chemistry Transport and Trajectory-based Receptor models}

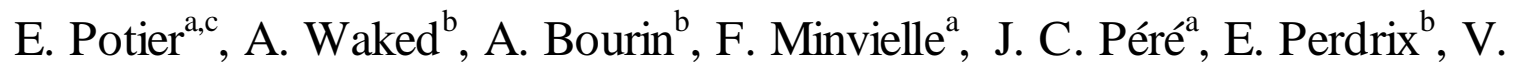
Michoud $^{\mathrm{b}, \mathrm{d}}$, V. Riffault, L. Y. Alleman ${ }^{\mathrm{b}}$, S. Sauvage ${ }^{\mathrm{b}}$

${ }^{a}$ Univ. Lille, CNRS, UMR 8518 - LOA - Laboratoire d'Optique Atmosphérique, F-59000 Lille, France.

${ }^{b}$ IMT Lille Douai, Univ. Lille, SAGE - Département Sciences de l'Atmosphère et Génie de l'Environnement, 59000 Lille, France.

${ }^{c}$ Now at Laboratoire des Sciences du Climat et de l'Environnement, LSCEIIPSL, CEA-CNRS-UVSQ, Université Paris-Saclay, F-91191 Gif-sur-Yvette, France

${ }^{d}$ Now at Laboratoire Interuniversitaire des Systèmes Atmosphériques (LISA); IPSL, UMR CNRS 7583, Université of Paris Est Créeteil (UPEC) and Paris Diderot (UPD), Créteil, France

Abbreviations:CTM, Che mistry Transport Model; BC, Black Carbon; BI, British Isles; BT, Back Trajectory; CF, Concentration Field; CRA, Cut-offs Rain and Altitude; HdF, Hauts-de-France reg ion; MFB, Mean Fractional Bias; MFE, Mean Fractional Error; MLA, Monthly Limit Altitude; OC, Organic Carbon; PBL, Planetary Boundary Layer; PM, Particulate Matter; PPM, Primary Particu late Matter (anhropogenic primary species); PSCF, Potential Source Contribution Function; RMSE, Root Mean Squared Error; SOA, Secondary Organic Aerosols; ST, Short-range Trajectory; TRM, Trajectory-based statistical Receptor Model; WF, Weighting Function 


\begin{abstract}
Atmospheric pollution is a striking regional issue for public health and ecosystems and has major global impacts on climate. Particulate matter (PM) can be of primary or secondary origin and its sources, both natural and anthropogenic, are very heterogeneo us in space and time. Hence, many efforts have been made worldwide to get a better knowledge of PM sources, in order to set effective reduction strategies. To this end, several distinct approaches may be used among which: (i) the localization of potential source areas with trajectory-based statistical receptor models (TRMs) which combine PM concentrations observed at receptor sites with computed back trajectories (BTs) of air masses, and (ii) the estimation of PM source contribution and chemical speciation with deterministic chemistry transport models (CTMs) based on emission inventories and detailed chemistry-transport processes. This study aims at testing the coherence between two independant approaches, CTMs and TRMs, for the geographical localization of the sources impacting a region of study. The case study refers to $\mathrm{PM}_{10}$ pollution in the Hauts-de-France region $(\mathrm{HdF})$ in the North of France for the year 2010. The considered TRMs are multi-site Concentration Field (CF) and Potential Source Contribution Function (PSCF) applied to 12 receptor sites using the Zefir package. The considered CTM is CHIMERE using detailed EDGAR European emission data. First, TRMs showed that some given far-located European countries (named "Far-East" countries ) could have a strong but infrequent impact on $\mathrm{PM}_{10}$ levels in the study region, while some given nearer European countries (named "Near-East" countries) had a frequent and predominant impact. Then, the contributions of each of these TRM-highlighted regions to $\mathrm{PM}_{10}$ concentrations over the study area were analyzed by CHIMERE simulations. The potential influence of another non TRM-highlighted region (i.e. the "British Isles") was also
\end{abstract}


studied for comparison. The CTM results confirmed the prevalence of the Near-East source area in terms of mas s contribution throughout the year and particularly during high-concentration periods. Therefore results obtained from CHIMERE CTM and multi-site CF and PSCF TRMs showed consistency, highlighting the interest for further compariso n of both CTMs and TRMs independent approaches in other regions as well as for other pollutants.

Keywords: CHIMERE, receptor model, PSCF, Concentration Field, $\mathrm{PM}_{10}$ sources 


\section{Introduction}

At the global scale, aerosols play an important role on climate by scattering and absorbing solar and terrestrial radiations, which contribute to both cooling and warming of the atmosphere (Boucher et al., 2013). At the regional scale, particles are known to have adverse health effects, especially small particles with diameters lower than $10 \mu \mathrm{m}$ and $2.5 \mu \mathrm{m}\left(\mathrm{PM}_{10}\right.$ and $\mathrm{PM}_{2.5}$ respectively) (WHO, 2003). Exposure to particulate pollution is notably more significant in urbanized areas where denser emissions are released due to the concentration of humans activities. In Europe, the Air Quality Directives limit values and the WHO Air Quality thresholds are often exceeded according to the data of the European air quality database (Air Quality e-reporting database, (EEA, 2017)).

The occurrence of these particulate pollution episodes is the result of complex processes involving direct primary emissions, physico-chemical transformations, transport and deposition, depending on meteorological factors. Among these processes, the variety of regionally spread sources and the atmospheric lifetime of compounds make the long-range transport of pollutants an important factor influencing the pollution over a given region. The Hauts-de-France region (HdF thereafter), located in the heart of a dense urbanized and industrialized area of northwestern Europe, is regularly impacted by $\mathrm{PM}_{10}$ pollution episodes of both local and regional origins (Favez et al., 2012; Bessagnet et al., 2005). Large scale particulate pollution episodes observed in the region were shown to be predominated by secondary aerosols (e.g. ammonium nitrate and sulfate; secondary organic aerosols (Beekmann et al., 2015)). Consequently, understanding the role of regional sources is needed to improve our comprehension of the occurrence of particulate 
pollution episodes in this specific region. For such an analysis, different modelling approaches such as deterministic eulerian Chemistry Transport Models (CTMs) or Trajectory-based Receptor-oriented statistical Models (TRMs) based on ambient air observations at sampling sites can be used. The originality of this study is to combine both approaches to accurately estimate the geographical origin of pollutant sources impacting $\mathrm{HdF}$.

Several CTMs are currently developed in Europe for both research and forecast purposes, like those in the ENSEMBLE system (CAMS, 2016): CHIMERE (INERIS, CNRS, France, (Menut et al., 2013)), EMEP (MET Norway, Norway, (Simpson et al., 2012)), EURAD (RIUUK, Germany, (Memmesheimer et al, 2004)), LOTOS-EUROS (KNMI, TNO, The Netherlands, (Schaap et al., 2008)), MATCH (SMHI, Sweden, (Andersson and Kahnert, 2016)), MOCAGE (Météo-France, France (Sic et al., 2015)) and SILAM (FMI, Finland, (Sofiev et al., 2015)). These models explicitly simulate the emission, physico-chemical transformations, transport and deposition of pollutants based on detailed emission inventories as well as empirical assumptions. Hence, they are well adapted to analyze the relative contributions of the variety of emission sources over a specific area. In this study numerical simulations were performed with the CHIMERE regional CTM using an approach similiar to Rea et al. (2015) who studied the contribution of different types of PM sources in the Euro-Mediterranean region, or Bessagnet et al. (2005) who performed sensitivity analyses on emission inventories to study the origin of PM pollution events over the Paris region in 2003.

A complementary Trajectory-based statistical approach for the determination of the geographical origins of sources using the combination of air mass back trajectories (BTs) calculations with pollutants concentrations observations at multiple receptor sites has been widely used in many studies (Petit et al., 2017a; Waked et al., 2014; Xie and Berkowitz, 2007; Polissar et 
al, 2001). Trajectory frequencies and residence time of air masses enable to identify air parcels responsible of an exposure to high levels of $\mathrm{PM}_{10}$ concentrations observed at the receptor sites. Among TRMs, the Concentration Field (CF) and the Potential Source Contribution Function (PSCF) models are used to characterize the transport of pollution over geographical areas. In the $\mathrm{CF}$ approach, the geographical origins of the sources are provided for all the range of concentration levels whereas with the PSCF method, a threshold of high pollutant concentrations is selected in order to identify only geographical origins during the most severe pollution episodes.

The main objectives of this work are to (1) compare two independant approaches, the CF/PSCF and the CTM for identifying the regional and continental sources of pollution and (2) quantify their contributions to the pollution over HdF. CF/PSCF and CTM methodologies are presented in Section 2. In Section 3 results for the entire year 2010 are analyzed, with a focus on pollution events. Section 4 discusses uncertainties relative to both approaches as well as their synergies and includes concluding remarks.

\section{Methodology}

\subsection{The study area}

The study area is HdF in Northern France (Fig. 1a, yellow highlights). It covers an area of 31,813 $\mathrm{km}^{2}$ and is influenced by many anthropogenic (e.g. residential and industrial sectors, agriculture as well as the transport sector) and biogenic emissions. The region encompasses many petrochemical, metallurgic and non-metallurgical industries. The coastal zone located near the strait of Dover and the English Channel is impacted by oceanic sea spray and shipping emissions. The region can also be influenced by long-range trans-boundary air pollution from Central Europe. $\mathrm{PM}_{10}$ annual and daily EU limit values are exceeded in many areas of HdF (Atmo-HdF, 2017). 
The climate is temperate with an oceanic influence characterized by mild temperatures (average annual values in the range of $\left.6-8^{\circ} \mathrm{C}\right)$ and regular precipitations amount $\left(600-800 \mathrm{~mm} \mathrm{yr}^{-1}\right)$. Winds are prevailing mostly from the South-West as well as from the North and North-East directions whereas insolation ranges from $1600-1700$ hours on a yearly basis.

\subsection{Trajectory-based receptor models}

\subsubsection{Input data}

Atmo spheric concentrations of $\mathrm{PM}_{10}$ were collected on an hourly basis for the year 2010 from 01/01 to 31/12 (http://www.atmo-hdf.fr/) from the regional Air Quality Monitoring Network Atmo Hauts-de-France. A total of twelve urban, sub-urban and rural sampling sites (Fig. 1b) covering the whole region were selected in a way that excluded an influence from temporary or specific local sources not representing the general characteristics of the studied region (e.g. sites influenced by temporary road works or by local industrial emissions). The $\mathrm{PM}_{10}$ atmospheric concentrations were measured by equivalent methods (e.g. TEOM-FDMS and Beta-Gauge) depending on the sampling sites. The equivalence to a reference method for sampling and measurement of $\mathrm{PM}_{10}$ concentrations had been demonstrated for all the used instruments (Verlac, 2017; Bihan et al., 2006). Missing values were in the range of 2-10\%.

BTs were calculated every $3 \mathrm{~h}$ for each day ( 8 trajectories per day) by means of the Linux-based version of the NOAA's Hybrid Single Particle Lagrangian Integrated Trajectory model (HYSPLIT). Each trajectory went back $72 \mathrm{~h}$ with a temporal resolution of $1 \mathrm{~h}$ (72 endpoints per trajectory) and an ending latitude-longitude coordinates corresponding to one of the twelve receptor sites chosen for the study. The input meteorological data for the HYSPLIT model (Stein et al., 2015) were retrieved from weekly NCEP's Global Data Assimilation (GDAS) System with a 
$1.0^{\circ} \times 1.0^{\circ}$ spatial resolution. The ending altitude of the BTs was $500 \mathrm{~m}$ above the ground level in order to reduce the effect of the surface friction and to represent winds in the boundary layer. It was found to be satisfactory and was used in many studies in the literature (Begum et al., 2005; Hafner and Hites, 2003; Gao et al., 1993). Input data (8 tri-hourly averaged $\mathrm{PM}_{10}$ concentrations matching 8 air mass BTs per day) were then used in the Zefir Igor package (Petit et al., 2017b) in order to plot geographical origin maps using CF and PSCF models. In both PSCF and CF methodologies, a regular $0.5^{\circ} \times 0.5^{\circ}$ grid was superimposed to the region encompassing the considered receptor sites and the computed air mass BTs. The $0.5^{\circ}$ x $0.5^{\circ}$ grid latitudes ranged from $37^{\circ} \mathrm{N}$ to $69^{\circ} \mathrm{N}$ and the longitudes from $26^{\circ} \mathrm{W}$ to $31^{\circ}$ E. PSCF and CF methodologies are briefly described in the following sub-sections and in further details in Waked et al. (2018).

\subsubsection{CF method}

The CF method (Petit et al., 2017b; Charron et al., 2013; Polissar et al., 2001; Seibert et al., 1994) uses the residence time of air masses in each grid cell to calculate a residence time-weighted $\mathrm{PM}_{10}$ concentration using the following equation:

$$
\log C_{i, j}=\frac{\sum_{l=1}^{M} n_{i, j, l} \times \log C_{l}}{\sum_{l=1}^{M} n_{i, j, l}}
$$

where $\mathrm{C}_{i, j}$ is the residence time-weighted concentration of the $\mathrm{ij}^{\text {th }}$ grid cell, $\mathrm{C}_{l}$ the concentration measured at the receptor site on the arrival of a trajectory $1, \mathrm{M}$ the total number of trajectories and $\mathrm{n}_{i, j, l}$ the residence time of an air mass trajectory 1 on a grid cell $\mathrm{ij}$. A geometric mean is used as the distribution of $\mathrm{PM}_{10}$ concentrations is log-normal and provides an estimation 
not skewed by extreme values.

The underlying assumption is that the longer an air mass stays in a grid cell, the more it may get polluted by the sources located in this grid cell. The residence time-weighted concentrations associated to each grid cell form a "concentration field". In the obtained CF map, a grid cell showing a high residence time-weighted concentration is interpreted as the possible location of a source area which impacts the considered receptor site. In multi-site CF (or PSCF), multiple receptor sites are considered simultaneously, thus increasing the spatial representativeness and the statistical power of the results. This was the case in this work where 12 receptor sites were considered (Fig. 1b).

\subsubsection{PSCF method}

The PSCF method (Pongkiatkul and Oanh, 2007; Zeng and Hopke, 1989) provides a probability field which can be used to determine the areas potentially responsible of high levels of $\mathrm{PM}_{10}$ concentrations above a given threshold measured at the receptor sampling sites (Li et al., 2012; Cheng et al., 1993) as follows:

$$
\operatorname{PSCF}_{i, j}=\frac{m_{i, j}}{n_{i, j}}
$$

where $\mathrm{n}_{i, j}$ is the total number of endpoints of BTs passing over a grid cell $\mathrm{ij}$ and $\mathrm{m}_{i, j}$ is the number of endpoints of BTs passing over the grid cell ij and having a $\mathrm{PM}_{10}$ concentration (a tri-hourly average in this study) measured at the receptor site higher than the chosen specific threshold (40 $\mu \mathrm{g} \mathrm{m}^{-3}$ during this study which corresponds to the EU annual limit value for $\mathrm{PM}_{10}$ ) in order to perceive the geographical origin of $\mathrm{PM}_{10}$ during the occurrence of pollution episodes. 


\subsubsection{Sensitivity analysis}

$P M_{10}$ depletion processes during air mass transport: In both CF and PSCF methods, the atmospheric lifetime of $\mathrm{PM}_{10}$ is taken into account through the given backtime of air mass trajectories (here $72 \mathrm{~h}$ ). In both methods, the influence of permanent sinks such as dry deposition and photochemical ageing is assumed to be comparable for all trajectories. Howewer this assumption does not apply in the case of temporary sinks such as rain events which only affect given trajectories at given locations and times. Therefore the effect of temporary sinks such as rain occuring during the transport of an air mass is generally neglected. In order to get a more realistic maps, precipitation data provided by HYSPLIT along the BTs were used to remove all the endpoints preceding a precipitation event with an intensity stronger than $1 \mathrm{~mm} \mathrm{~h}^{-1}$ (Kim et al., 2014) due to the fact that heavy precipitations are believed to strongly decrease $\mathrm{PM}_{10}$ concentrations. In addition, another phenomenon which may reduce the $\mathrm{PM}_{10}$ concentration of an air parcel is its dilution in the free troposphere. Therefore, endpoints for which altitude was above the Planetary Boundary Layer (PBL) height were removed along with all the preceding endpoints. To do so, monthly limit altitudes (MLA) established as representative of the separation between the PBL and the free troposphere (Table 1) were used. These MLA were measured at noon at a comparable site in term of latitude in Germany from 2000 to 2009 by von Engeln and Teixeira (2013). The use of constant MLA from measurements instead of using the variable PBL heights simulated in GDAS fields was preferred as it enables to minimise the excessive removal of nighttime endpoints due to the high uncertainty in the simulation of the nocturnal residual boundary layer (Waked et al., 2018). It should be noted that when endpoints were removed for precipitations and altitude, the air mass age of BTs was reduced and became lower than $72 \mathrm{~h}$.

Spatial density of the BTs: A weighting function $\mathrm{W}_{i, j}$ included within the Zefir package 
(Petit et al., 2017b) was used for both the CF and PSCF methods in order to down-weight grid cells presenting a low number of endpoints as follows:

$$
W_{i, j}=\left\{\begin{array}{rrr}
1 \times C_{i, j} & \text { for } & \log \left(n_{i, j}+1\right) \geq 0.85 \times \max \left[\log \left(n_{i, j}+1\right)\right] \\
0.725 \times C_{i, j} & \text { for } & 0.85 \times \max \left[\log \left(n_{i, j}+1\right)\right]>\log \left(n_{i, j}+1\right) \geq 0.6 \times \max \left[\log \left(n_{i, j}+1\right)\right] \\
0.475 \times C_{i, j} & \text { for } & 0.6 \times \max \left[\log \left(n_{i, j}+1\right)\right]>\log \left(n_{i, j}+1\right) \geq 0.35 \times \max \left[\log \left(n_{i, j}+1\right)\right] \\
0.175 \times C_{i, j} & \text { for } & \log \left(n_{i, j}+1\right)<0.35 \times \max \left[\log \left(n_{i, j}+1\right)\right]
\end{array}\right.
$$

where $\mathrm{n}_{i, j}$ is the total number of endpoints in the $\ddot{\mathrm{ij}}^{\text {th }}$ grid cell.

When using the weighting function (WF), concentrations corresponding to frequent air mass trajectories are given more weight and consequently the highlighted potential source areas are supposed to concur frequently to the observed pollution. In addition, as the spatial density of back trajectory endpoints is higher when getting closer to a receptor site, the most distant endpoints are less frequently observed. Therefore the application of the WF gives maps corresponding to medium-range BTs, hereafter named as "medium-range maps". Conversely without the weighting function, the potential source areas found may correspond to exceptional situations not so frequently observed and to sources located at a long distance from the receptor site. These maps are called "long-range" maps.

Short-range back-trajectories: Lastly, in order to perceive the impact of the local and nearest regional sources on the concentrations measured at the receptor sites, the following equation was used to calculate the great distance circle between a BT endpoint and the receptor site:

$$
S_{A-B}=6378 \times \cos ^{-1}\left(\sin \alpha_{A} \sin \alpha_{B}+\cos \alpha_{A} \cos \alpha_{B} \cos d \beta\right)
$$

with, 6378 (the earth radius), A the receptor site and B the considered endpoint of the BT, $\mathrm{S}_{A-B}$ the distance in $\mathrm{km}$ from the trajectory endpoint to the receptor site, $\alpha_{A}$ and $\alpha_{B}$, the latitudes in 
radians of respectively $\mathrm{A}$ and $\mathrm{B}$, and $\mathrm{d} \beta$, the difference between the longitudes in radians of $\mathrm{B}$ and A. The trajectories that contained $75 \%$ or more of their 72 endpoints within a distance of $500 \mathrm{~km}$ (i.e. at least $75 \%$ of endpoints with $\mathrm{S}_{A-B} \leq 500 \mathrm{~km}$ ) from the receptor site were kept. The spatial grid resolution for the trajectory output maps (called "short-range maps") was increased to $0.1^{o} \mathrm{x}$ $0.1^{\circ}$. The dimensions of the short-range maps are in latitude $48^{\circ} \mathrm{N}$ to $52.6^{\circ} \mathrm{N}$ and in longitude from $5^{\circ} \mathrm{W}$ to $8.25^{\circ}$ E. It should be noted that after the selection of short trajectories, around 3500 BTs for all the twelve sampling sites were kept in comparison with the 35000 long and medium range BTs. Nevertheless, this number remains sufficiently high to be considered statistically representative, therefore enabling the calculation of the CF and PSCF maps.

\subsubsection{Uncertainty evaluation}

In this study, a qualitative uncertainty assessment was performed for the output CF/PSCF maps taking into account the precision of the input data. The uncertainty of the measured tri-hourly concentrations of $\mathrm{PM}_{10}$ was estimated to be less than $50 \%$ (Kiss et al., 2017). However, because the deterministic CTM approach considers measured $\mathrm{PM}_{10}$ concentrations as "true" values, here the uncertainty of the measured values will not be considered. The uncertainty related to the meteorological data was evaluated by comparing the CF/PSCF maps obtained using $1.0^{\circ} \times 1.0^{\circ}$ GDAS meteorological data with the use of GDAS data with a higher spatial resolution of $0.5^{\circ} \mathrm{x}$ $0.5^{\circ}$ for the period from $05 / 08 / 10$ to $31 / 12 / 10$ (i.e. the common period of availability of GDAS data with both spatial resolutions). The obtained maps showed non-significant differences with correlation coefficients of around 0.9 and average absolute relative deviations of about $2 \%$ for both the CF and PSCF. These results compare well with the position error of $20 \%$ found by (Kiss et al., 2017) for trajectories computed from analyzed wind fields. Lastly, the influence of the 
spatial resolution of the gridded domain was also tested within the Zefir package considering grid cells of $1.0^{\circ} \times 1.0^{\circ}, 0.5^{\circ} \times 0.5^{\circ}$ or $0.1^{\circ} \times 0.1^{\circ}$ in size and was considered low with a maximum average absolute relative deviations of $24 \%$ since non-significant differences in geographical source area maps were observed. It should be noted also that the maps obtained by constraining the BTs (cut-off for rain and altitude, short-range trajectories) should present less spatial uncertainty than the non-constrained maps because of the shortening of constrained BTs. It is in fact well-established that shorter BTs are more accurate than longer ones (Charron et al., 1998) leading to less uncertainty of the cell estimate for these CF and PSCF maps. Therefore, the global qualitative uncertainty in the geographical origin source maps (CF and PSCF) was considered as low and would be in the range of $20-30 \%$.

\subsection{Chemistry-transport model approach}

\subsubsection{Description of CHIMERE}

The model version used in this study was CHIMERE2016a. All simulations were performed for the year 2010 over a domain represented on Fig. 1 and with a model configuration summarized in Table 2. The studied domain was HdF in a larger simulation domain that covered a large part of Europe, to obtain a detailed representation of the variety of regional pollutant sources. The horizontal simulation mesh grid was $0.2^{\circ}$ in latitude and $0.2^{\circ}$ in longitude and the vertical grid was composed of 15 levels from the surface (top of the first layer $997 \mathrm{hPa}$ ) to $500 \mathrm{hPa}$. CHIMERE simulates gas-phase chemistry, aerosol formation, transport and deposition at urban and regional scales by using information on gaseous and particulate emissions. Anthropogenic emissions came from the EDGAR-HTAP-V2 European inventory at a resolution of $0.1^{\circ}$ x $0.1^{o}$ for the year 2010 (Janssens-Maenhout et al., 2012). The available emitted masses for methane (CH 
${ }_{4}$ ), non- methane organic volatile compounds (NMVOC), carbon monoxide (CO), sulfur dioxide $\left(\mathrm{SO}_{2}\right)$, nitrogen oxides $\left(\mathrm{NO}_{x}\right)$, ammonia $\left(\mathrm{NH}_{3}\right), \mathrm{PM}_{10}, \mathrm{PM}_{2.5}$, black carbon (BC) and organic carbon (OC) were disaggregated into model species and mapped onto the chosen simulation grid with a specific CHIMERE preprocessing. Biogenic emissions were calculated on-line using the global Model of Emissions of Gases and Aerosols from Nature (MEGAN; (Guenther et al., 2006)). It should be noted that mineral dust emissions were not activated in this study as we focused primarily on the impact of anthropogenic pollution. Furthermore in-situ measurements in North Europe showed that the contribution of dust in the aerosol composition is small (5-12\%, Putaud et al. (2010)). Initial and boundary conditions for chemistry came from monthly climatology (5-years averaged) of the LMDZ-INCA model (Hauglustaine et al., 2014). CHIMERE also uses as inputs meteorological informations (such as temperature, wind, humidity,...) provided by the Weather Research and Forecasting model at a one hour resolution (WRF; (Skamarock et al., 2008)).

In this study, several simulation tests were performed with modifications on these anthropogenic emissions detailed in section 2.3.3 and reported in Table 2.

\subsubsection{Evaluation}

The meteorological fields used to drive the CHIMERE model were compared to European meteorological measurements available in 2010. Surface temperature, zonal and meridional wind speeds were evaluated with measurements from 43 French, English, Belgian and German airports gathered in the meteorological database of the University of Wyo ming (http://weather.uwyo.edu). Precipitations were evaluated against daily cumulated precipitations measured at 12 French and German EMEP sites (http://ebas.nilu.no). In order to evaluate $\mathrm{PM}_{10}$ modeled concentrations, measurements from 123 French, English, Belgian, Dutch and German air quality monitoring sites 
were used (AirBase, https://www.eea.europa.eu). Localizations of the air quality and meteorological measurement sites used in this study are displayed on Fig. 2.

Hourly $\mathrm{PM}_{10}$ concentrations from the model in the surface layer were daily averaged and then statistics were used to compare measured $\left(\mathrm{C}_{\text {obs }}\right)$ and modeled $\left(\mathrm{C}_{\text {mod }}\right)$ compound concentrations. Spatio-temporal average $(\mu)$ and standard deviation $(\sigma)$ were calculated on the whole $\mathrm{PM}_{10}$ concentration dataset at the sites and their corresponding mesh, with $\mathrm{N}$ the number of data. $\mathrm{N}=$ number of daily data $\times$ number of numerical mesh (or number of sites):

$$
\begin{gathered}
\mu=\frac{\sum_{i-1}^{N} C_{i}}{N} \\
\sigma=\sqrt{\frac{\sum_{i=1}^{N}\left(C_{i}-\mu\right)^{2}}{N}}
\end{gathered}
$$

Statistical indicators were used to evaluate the agreement between observations and modeled surface concentrations: the Pearson correlation coefficient (r) is calculated by dividing the covariance of the two variables $\left(\mathrm{C}_{o b s}\right.$ and $\left.\mathrm{C}_{\text {mod }}\right)$ by the product of their standard deviations. It reflects the linear relationship between the two variables. The data are considered moderatly correlated when $\mathrm{r}$ reaches 0.5 and strongly correlated when $\mathrm{r}$ gets close to 1 . The root mean squared error (RMSE) is also calculated. It can be interpreted as the standard deviation of the unexplained variance. The lower the RMSE, the better the model fits the observations.

$$
R M S E=\sqrt{\frac{\sum_{i=1}^{N}\left(C_{i}^{\text {mod }}-C_{i}^{o b s}\right)^{2}}{N}}
$$

Statistical indicators such as the mean fractional error (MFE) and the mean fractional bias (MFB) between observations and modeled surface concentrations, were also used as 
recommended in air quality simulation performance evaluation (Boylan and Russell, 2006).

$$
\begin{aligned}
& M F B=\frac{1}{N} \sum_{i=1}^{N} \frac{C_{i}^{\text {mod }}-C_{i}^{o b s}}{\left(C_{i}^{\text {mod }}+C_{i}^{o b s}\right) / 2} \\
& M F E=\frac{1}{N} \sum_{i=1}^{N} \frac{\left|C_{i}^{\text {mod }}-C_{i}^{o b s}\right|}{\left(C_{i}^{\text {mod }}+C_{i}^{o b s}\right) / 2}
\end{aligned}
$$

MFB indicates systematic errors which lead to always underestimate or overestimate the measured values. It can vary between $-200 \%$ (extreme under-estimation) to $+200 \%$ (extreme over-estimation). MFE avoids compensations between over- and under-estimations. It varies between $0 \%$ to $+200 \%$. Values of zero for both MFB and MFE indicate an ideal model. As defined by Boylan and Russell (2006), we considered that if both $|M F B|$ and MFE were lower or equal to $30 \%$ and $50 \%$ respectively, the performance goals were achieved and if they were lower or equal to $60 \%$ and $75 \%$ respectively, the model met the performance criteria.

\subsubsection{Area contribution calculations}

A recent study carried out by research scientists and the $\mathrm{HdF}$ air quality monitoring network (Atmo-HdF, 2010; Petit et al, 2017a; Waked et al., 2018) highlights that air masses coming from three different areas mainly impact HdF: the South-South-West, the North-West, and the North-East. These areas can then be seen as potential sources of pollution affecting the air quality over HdF. More specifically, two directions were explored in this work: the North-West and the North-East with two distance levels from HdF for this last direction, defining three areas displayed on Fig. 1. The first one corresponds to the area including the British Isles (BI thereafter), the second one called the Near-East covers Benelux/Germany and the western part of the Czech Republic and the third one, called Far-East, covers Poland/Slovakia and the eastern part of the Czech-Republic. The study of this last area was prioritized instead of Paris region in accordance to 
results of the CF/PSCF approach (Sect. 3.1). To study the potential transport of pollutants from these 3 areas over HdF, 3 tests were performed in which all anthropogenic emissions over the specific area have been set to zero.

Each of the three areas contributions ( $\Delta \mathrm{C}^{\text {area }}$ ) was calculated as the difference between the concentration of $\mathrm{PM}_{10}$ in the reference simulation (including all emitting areas), $\mathrm{C}^{\text {ref }}$, and the concentration of $\mathrm{PM}_{10}$ in the simulation without anthropogenic emission in the selected area $\mathrm{C}$ Warea :

$$
\Delta C_{m, h}^{\text {area }}(\%)=\frac{C_{m, h}^{r e f}-C_{m, h}^{\text {Warea }}}{C_{m, h}^{r e f}} \times 100
$$

with $\mathrm{m}$ corresponding to mesh in $\mathrm{HdF}$ and $\mathrm{h}$ to hourly time step. Maps of the contributions averaged on the full year or per season were generated. Averaged standard deviations were also calculated as:

$$
\begin{gathered}
\sigma_{t}=\left\langle\sqrt{\frac{\sum_{h=1}^{H}\left(\Delta C_{m, h}^{\text {area }}(\%)-\overline{\Delta C_{m, h}^{\text {area }}(\%)}\right)^{2}}{H}}\right\rangle \\
\sigma_{s}=\sqrt{\frac{\sum_{m=1}^{M}\left(\Delta C_{m, h}^{\text {area }}(\%)-\left\langle\Delta C_{m, h}^{\text {area }}(\%)\right\rangle\right)^{2}}{M}}
\end{gathered}
$$

where $\overline{\Delta C_{m, h}^{a r e a}}$ denotes the temporal mean on the considered $\mathrm{H}$ period (year, season) and $\left\langle\Delta C_{m, h}^{\text {area }}\right\rangle$ denotes the spatial mean on the M meshes in HdF.

Distinctions have also been made between contributions to background levels and contributions to pollution events. For this purpose, a threshold on $\mathrm{PM}_{10}$ concentrations in the reference simulation was fixed to $25 \mu \mathrm{g} \cdot \mathrm{m}^{-3}$. We reduced the official threshold of $50 \mu \mathrm{g} \mathrm{m}^{-3}$ 
on daily concentrations since the modeled $\mathrm{PM}_{10}$ concentrations are representative of the model meshgrid scale and may correspond to higher local concentrations. Sensitivity tests were performed: contributions of the 3 areas were calculated when modeled hourly PM ${ }_{10}$ concentrations were above 10,20,30,40, and $50 \mu \mathrm{g} \mathrm{m}^{-3}$ in the reference simulation (Results not shown). Then the threshold was refined between 20 and $30 \mu \mathrm{g} \mathrm{m}^{-3}$ and we found that $25 \mu \mathrm{g} \mathrm{m}$ ${ }^{-3}$ seemed a good compromise. It was high enough to be representative of model pollution level and it gave a sufficient number of model exceedances regarding measurements. With a threshold of $25 \mu \mathrm{g} \mathrm{m}^{-3}$, around $5 \%$ of the dataset was regarded as polluted.

$\mathrm{PM}_{10}$ aerosols are composed of different chemical species. The main species simulated by CHIMERE are: nitrate, sulfate, ammonium, black carbon, organic carbon, anthropogenic primary species (PPM: primary particulate matter, e.g. from anthropogenic erosion processes) and secondary organic aerosols (SOA). The influence of the three areas (BI, Near-East, Far-East) on the aerosol chemical composition modeled over HdF will be also analyzed.

\section{Results}

\subsection{CF/PSCF potential source areas maps}

Maps of the geographical origin of potential source areas impacting HdF in 2010 optimized by taking into account the cut-offs for precipitations and altitude (CRA) are plotted in Fig. 3 for long trajectories (without WF), medium-range trajectories (applying the WF) and short-range trajectories (selecting trajectories with $75 \%$ of endpoints within $500 \mathrm{~km}$ around the receptor sites) using both the CF (considering all days) and the PSCF models (only for pollution episodes up to 40 $\left.\mu \mathrm{g} \mathrm{m}^{-3}\right)$. 
The long-range CF results used for the investigation of the geographical origin of the $\mathrm{PM}_{10}$ sources with all the measured data showed highest contributing areas mainly from central Europe (e.g. north of Italy, Germany, Austria, Czech Republic, Hungary, Slovakia, south of Poland) as well as from the west of Ukraine and of Belarus (Fig. 3a, CF+CRA). The application of a WF for the CF maps in order to investigate medium-range trajectories frequently impacting HdF showed an important influence from nearer areas such as the Benelux, west of Germany as well as HdF itself (Fig. 3c, $\mathrm{CF}+\mathrm{CRA}+\mathrm{WF}$ ). Investigating the impact of nearest regional sources with the selection of short trajectories highlighted a significant influence of the Benelux area as well as the west of Germany (e.g. the Ruhr region) with high geometric averaged concentrations ranging from 40-60 $\mu \mathrm{g} \mathrm{m}^{-3}$ (Fig. 3e, CF+ST+CRA). This regional map showed a significant influence of short-distant sources in HdF when a weighting function was further applied, in particular from cities densely populated such as the Lille Metropolitan area as well as the capital city of Paris in accordance with emission inventory maps for Europe (Pay et al., 2012) (Fig. 3g, $\mathrm{CF}+\mathrm{CRA}+\mathrm{WF}+\mathrm{ST})$. It is worth noting that the averaged $\mathrm{PM}_{10}$ concentrations associated with short-range BTs highlighting Lille and Paris as potential origins sources do not exceed $30 \mu \mathrm{g} \mathrm{m}$ -3 (i.e. are rather limited) and represent solely around $50 \%$ of the maxima observed for the long-range map. Also the short-range BT maps represent only a limited period of the year (around $10 \%$, as explained in section 2.2.4) when anticyclonic conditions are centered over the $\mathrm{HdF}$ region. Therefore the rather higher $\mathrm{PM}_{10}$ averages obtained in the HdF region for $\mathrm{ST}$ maps in comparison to long and medium-range trajectory maps under similar constraints (e.g. when comparing Fig. 3a with Fig. 3e under CRA constraint, or Fig. 3b with Fig. 3f under CRA+WF constraints) are explained by these HdF-centered low-wind anticyclonic conditions which favour the accumulation of pollution over the $\mathrm{HdF}$ region and highlight the influence of local sources. 
Therefore it may be concluded that the particulate pollution observed in $\mathrm{HdF}$ is for a small part related to long-range trans-boundary pollution which is unfrequent but may contribute to high PM ${ }_{10}$ concentrations (in the range of $40-60 \mu \mathrm{g} \mathrm{m}^{-3}$ ), for a large part to frequent medium-range transboundary pollution from neighbouring countries (mainly Belgium and Germany) giving moderate $\mathrm{PM}_{10}$ concentrations (up to $30 \mu \mathrm{g} \mathrm{m}^{-3}$ ), and that another significant part is due to nearest contribution from the French territory giving also moderate $\mathrm{PM}_{10}$ concentrations.

Using the PSCF method to identify the geographical origins of potential $\mathrm{PM}_{10}$ sources associated with the highest concentrations $40 \mu \mathrm{g} \mathrm{m}^{-3}$ observed in HdF (i.e. during pollution episodes), it was found that the region of Central Europe, in particular, Austria, Hungary, west of Ukraine and Belarus, had high probability levels (contributions more than $80 \%$ ) during episodes of particulate pollution (Fig. 3b, PSCF+CRA). For medium and short-range trajectories, geographical origin maps during episodes showed comparable results to that of the CF method where the region of the Benelux area and Germany were highlighted whereas on a more regional scale, HdF (e.g. Lille metropolitan area; Belgian borders near the Lille area) and to a lesser extent the Paris area are identified with conditions probabilities ranging from 30 to $50 \%$ (Fig. 3, $\mathrm{PSCF}+\mathrm{CRA}+\mathrm{WF}(\mathrm{d})$ and $\mathrm{PSCF}+\mathrm{CRA}+\mathrm{WF}+\mathrm{ST}(\mathrm{h}))$.

On a seasonal scale, long-range BTs investigated using both CF and PSCF methods showed the highest concentrations of the contributing areas in winter and spring and the lowest in summer (Fig. 4, CF+CRA(a-d) and PSCF+CRA(i-j)). While during the winter season, potential source areas tend to be closer in term of distance to HdF (e.g. Germany, Austria and west of Slovakia), during the spring season, more distant potential source areas were identified in the west of Poland and Belarus, especially during pollution episodes (Fig. 4 PSCF+CRA(i-j) seasonal 
maps). These high concentrations of $\mathrm{PM}_{10}$ for longer BTs could be related to their enrichment with secondary pollutants (e.g. ammonium sulfate) or gaseous precursors of these pollutants as already found in the literature (Waked et al., 2014; Pay et al., 2012; Petit et al., 2017a). For instance trans-bound ary pollution related to more distant sources showed a contribution around 50 $\%$ during and outside episodes. This is due to the fact that, when WF was used, the conditional probabilities as well as the concentrations of $\mathrm{PM}_{10}$ for the nearest sources were reduced by a factor of two on average. The use of a WF showed also that when back trajectories frequently impacting $\mathrm{HdF}$ are selected, the identified potential geographical areas are the west of Germany, Benelux and the region of northern France and Paris. These areas appear with the highest concentrations during winter due to probably more intense sources (e.g. residential wood burning) and to lower PBL height which hinders dilution of pollutants. In the spring and fall seasons, pollution episodes impacting HdF (i.e. PSCF results), showed higher contributions from more distant geographical areas such as Germany, west of Poland and Austria highlighting the potential role of transboundary transport.

Seasonal variations of short-range trajectories CF maps showed the highest concentrations during the winter season and the lowest concentrations during summer (Fig. 5 ). Identified potential areas are located in Belgium, in the west of Germany in the Ruhr region (e.g. coal combustion power plants and industries), in the region near the Strait of Dover (e.g. mouth of the Rhine river (Petit et al., 2017a)) where major French harbors, industrial areas as well as intense shipping activities are located (Bressi et al., 2014) and in highly populated cities in France (e.g. Lille metropolitan area) and Belgium (e.g. Brussels, Ghent and Antwerp). The use of the WF for short trajectories showed clearly the influence of the Paris area for all seasons with the highest concentrations reported in winter (Fig. 5, CF+CRA+WF(e-h) seasonal maps). Using the PSCF 
model for the investigation of pollution episodes, a significant influence is shown in winter and fall from the eastern part of $\mathrm{HdF}$, namely the Aves nois rural area where biomass burning activities are intense, as well as from the cities of Maubeuge, Paris and Metz. In contrast, during the warmest seasons (spring and summer), there is no remarkable influence from these areas highlighting the likely impact of residential heating as an important source during winter/fall seasons. Indeed, according to Waked et al. (2014) during a study conducted in Lens in northern France, the contribution of biomass burning activities to total $\mathrm{PM}_{10}$ is higher during winter by a factor of 4 on average in comparison to the spring season.

\subsection{CTM approach}

\subsubsection{Evaluation of the main meteorological and chemical parameters}

The formation, transport and thus concentration of air pollutants can be sensitive to meteorological parameters such as wind, air temperature or precipitation. As a first step, it is thus important to evaluate the capability of the meteorological WRF model to reproduce these main meteorological parameters for the year 2010. The input surface temperature, zonal and meridional wind speeds and precipitation simulated by WRF for the year 2010 were compared to available European meteorological measurements. The results, displayed in Table 3, show good agreements. The modeled and measured meteorological parameters were strongly to very strongly correlated with $\mathrm{r}$ in the range $0.70-0.82$ for the both zonal and meridional wind speeds and $0.83-0.91$ for the temperature. For each variable, RMSE was lower than or in the order of magnitude of its standard deviation. Simulated precipitation amounts were moderately correlated to measured ones $(\mathrm{r}=$ 0.31-0.56), indicating that WRF is able to reproduce the main precipitation events over the year. These scores are similar to the ones obtained by Zhang et al. (2013) who performed an extensive 
validation of the WRF meteorological modelover Western Europe for the year 2001 ( $\mathrm{r}$ in the range 0.4-0.5 for precipitations, $0.5-0.9$ for wind and 0.9 for temperature).

In a second step, the surface $\mathrm{PM}_{10}$ concentration modeled by CHIMERE were evaluated with measurements from the AirBase database. CHIMERE simulation for the reference scenario (including all emitting areas) indicated surface $\mathrm{PM}_{10}$ hourly concentrations over HdF between 5 and $100 \mu \mathrm{g} \mathrm{m}^{-3}$ for 2010 . Figure 6 indicates that the annual means of $\mathrm{PM}_{10}$ concentrations were in the range 5-14 $\mu \mathrm{g} \mathrm{m}^{-3}$. These values at the model meshgrid scale are typically lower than measurements that represent local scale and are mostly near urbanized areas. The north of HdF, corresponding to the Lille Metropole, and the south border, near the Paris region, presented the highest annual concentrations (10-12 $\left.\mu \mathrm{g} \mathrm{m}^{-3}\right)$ but also the highest variability $\left( \pm 7 \mu \mathrm{g} \mathrm{m}^{-3}\right)$. Figure 6 also shows that the maximum concentrations around $100 \mu \mathrm{g} \mathrm{m}^{-3}$ were reached near the Paris region whereas the largest number of polluted hours $\left(\mathrm{PM}_{10}\right.$ concentrations larger than $25 \mu$ $\mathrm{g} \mathrm{m}^{-3}$ ) was simulated over the Lille Metropole area. In this area hourly $\mathrm{PM}_{10}$ surface concentrations above $25 \mu \mathrm{g} \mathrm{m}^{-3}$ were simulated during 800 hours for the year 2010 ( $9 \%$ of the year).

Table 4 presents statistical scores for surface $\mathrm{PM}_{10}$ concentrations simulated by CHIMERE. Comparisons between simulations and measurements indicated that spatio-temporal correlations were lower compared to the meteorological variables $(r=0.17-0.49$, depending on seasons). However, they remained similar to current performances of state-of-the-art air quality models used in the Air Quality Model Evaluation International Initiative (AQMEII) project (Im et al., 2015). RMSE was in the range 10-20 $\mu \mathrm{g} \mathrm{m}^{-3}$ and MFB was lower than $60 \%$ for all seasons (19-58 \%) suggesting that the model performance criteria was met. Although some model biases 
were present, CHIMERE was able to reproduce the development and transport of the main $\mathrm{PM}_{10}$ plumes over Europe for the year 2010.

\subsubsection{Contributions of areas to $P M_{10}$ concentrations over $H d F$}

In this part, the potential contribution of the 3 areas (BI, Near-East and Far-East) to $\mathrm{PM}_{10}$ over $\mathrm{HdF}$ is assessed using simulation results from the CHIMERE model and using the methodology described in section 2.3.3.

On an annual mean, Table 5 shows that contributions of $\mathrm{BI}$ and Near-East to $\mathrm{PM}_{10}$ concentrations over HdF were very similar. Results of simulations indicated that $17 \pm 23 \%$ of $\mathrm{PM}_{10}$ modeled come from each of these two areas. Also, 5.8 to $6.9 \%$ of the $\mathrm{PM}_{10}$ spatial variability simulated over HdF was due to these 2 areas. The influence of the Far-East was minor in our simulations with a contribution of $2 \pm 5 \%$ over the year.

On a seasonal basis, the 3 studied areas contributed individually within $0-25 \%$ to $\mathrm{PM}_{10}$ concentrations in average over $\mathrm{HdF}$ (Table 6), which corresponded to an additional concentration of 0 to $4 \mu \mathrm{g} \mathrm{m}^{-3}$ (Fig. 7). Contrarily to annual average, seasonal averages revealed differences between BI and Near-East contributions. It appeared that the largest contributions of $\mathrm{PM}_{10}$ came from the Near-East, in particular, during winter and spring seasons $(18.8 \%$ and $25.2 \%$ respectively, Table 6). The influence of BI was also important in summer, around $23 \%$, but corresponded to lower absolute values (Fig. 7, around $2 \mu \mathrm{g} \mathrm{m}^{-3}$ in average over HdF) when Near-East contribution in winter and spring reached $3.7 \mu \mathrm{g} \mathrm{m}^{-3}$ in average over HdF. The very low seasonal influence of the Far-East was confirmed, with a contribution lower than $2.6 \pm 5 \%$, corresponding to additional concentrations lower than $1 \mu \mathrm{g} \mathrm{m}^{-3}$ as highlighted in Table 6 and 
Fig. 7.

The influence of the 3 studied areas on hourly $\mathrm{PM}_{10}$ concentrations, modeled over HdF, during pollution events ( $\geq 25 \mu \mathrm{g} \mathrm{m}^{-3}$ ), was also evaluated. Table 5 shows that the Near-East contribution prevailed and accounted for $43 \%$ in $\mathrm{HdF} \mathrm{PM}_{10}$ concentrations while BI and Far-East contributed only to $7.7 \%$ and $2.7 \%$ respectively. We also observed that the Near-East contribution increased with increasing threshold to define polluted events. Polluted days influenced by Near-East occurred mainly in spring and winter, as highlighted on Fig. 8. The occurrence of polluted particulate events are more frequent during the se seasons (Guerreiro et al., 2014).

In terms of spatial variability, no clear differences could be observed between the northern and the southern part of HdF (Fig. 8). The Near-East, Far-East and BI contributed to PM 10 pollution events over the entire HdF, except during summer where the southern part of HdF seemed barely impacted by the three potential source areas. Largest contributions from Near-East appeared in the eastern part of $\mathrm{HdF}$ in spring while they are larger in the western part of HdF in fall. It should be noted that the southern part of HdF was likely impacted by pollutants coming from the Paris region.

\subsubsection{Impact of BI and Near-East emissions on the aerosol chemical composition over HdF}

In this section, the mean aerosol chemical composition modeled by CHIMERE over HdF for the reference scenario (including all emitting areas) is presented. Also, we discuss how the contribution of the studied areas (BI and Near-East) can modify this chemical speciation. Results for Far-East will not be presented as the influence of this region was found to be very low.

The reference simulation showed that $\mathrm{HdF}$ was mainly influenced by inorganic species for 
all seasons (Fig. 9a). In yearly mean, aerosols were dominated by nitrate (40.2\%), followed by sulfate $(19.2 \%)$ and ammonium $(18.1 \%)$. This result is consistent with observational studies highlighting that an important fraction of aerosols over northern France is constituted by inorganics (Putaud et al., 2004; Waked et al., 2014; Oliveira, 2017). The fraction of nitrates was lower in summer $(30.4 \%)$ than in winter $(45.3 \%)$. Inversely, the fraction of sulfates increased from winter (14.6\%) to summer $(27.4 \%)$ while the proportion of ammonium remained constant over 2010 (17.2-19.1\%). Primary organic matter (PPM+OC, see Fig. 9) was also an important constituent of aerosols throughout the year (17-19\%).

When BI and Near-East emissions were removed, the modeled proportion of nitrates was decreased by about 3-7 \% with the largest impact in spring and summer. This suggests that both areas act as emitters of nitrate gaseous precursors for $\mathrm{HdF}$ (Fig. 9 b-c). On the contrary, sulfates and ammonium proportions were very little impacted by these emissions. As a consequence of a higher summer proportion of nitrate over $\mathrm{HdF}$ due to $\mathrm{BI}$ and Near-East emissions, the proportion of primary organic matter was shown to decrease during this season $(2-5 \%)$ when emissions of these two areas were removed in the CHIMERE simulation.

\section{Discussions and concluding remarks}

In this study the CHIMERE CTM deterministic model used for Europe, as well as the CF/PSCF trajectory-based statistical receptor models run on the Zefir Igor package using HYSPLIT BTs, were used for the first time to the best of our knowledge as complementary approaches, in order to identify the possible geographical origins of $\mathrm{PM}_{10}$ sources impacting $\mathrm{HdF}$ during the year 2010. Regarding uncertainty assessment of both methodologies, the results obtained from the CF/PSCF approaches are estimated to be within $30 \%$ (e.g. spatial resolution as 
well as uncertainties in the GDAS input data) whereas uncertainties related to CTM outputs are evaluated against statistical indicators and are within the range of 20-60\%. The results obtained concerning these potential pollution source areas affecting HdF could be used in order to develop action plans for reducing air pollution. For instance, 20 exceedance days (above $25 \mu \mathrm{g} \mathrm{m}^{-3}$ threshold) were counted for 2010 on a daily observation basis averaged over the 12 sampling sites used in the CF/PSCF approach. These exceedance days occurred mostly in winter (65\%), spring $(23 \%)$ and fall $(12 \%)$ consistent with the fact that France as well as Western Europe is frequently subject to large-scale PM pollution episodes, notably during winter and spring (Vieno et al., 2016; Petit et al., 2017a; Favez et al., 2012; Bessagnet et al., 2004). Comparison of the results between the two complementary approaches (CF/PSCF and CTM) revealed an important trans-boundary contribution to $\mathrm{PM}_{10}$ concentrations in $\mathrm{HdF}$ originating from the Near-East "Benelux, Germany and west of Czech Republic" area. The CF and PSCF results suggested also a possible impact from the Far-East "Poland, Slovakia and East of the Czech Republic" region; however, air masses coming from this area do not frequently impact HdF. Furthermore, the impact of the BI region was shown to be less significant in comparison to that of the Near-East region during pollution episodes observed in HdF for 2010.

According to the CTM model, the chemical speciation of background $\mathrm{PM}{ }_{10}$ concentrations showed a predominance of secondary inorganic aerosols with nitrate, ammonium and sulfate accounting for $77 \%$ of the average mass. Highest recorded contributions occured in spring (79\%) and fall (78.3\%) and lowest recorded contributions in summer (75\%). This shows a possible effect of more aged air-masses for spring and fall seasons where contributions of secondary $\mathrm{PM}_{10}$ are therefore slightly increased. Indeed, according to CF and PSCF results, a higher contribution of more distant areas is more perceived during the spring season. Comparison 
to measurement data reported for $\mathrm{HdF}$ (Waked et al., 2014) showed, for 2011, a contribution from secondary inorganic compounds in the range of 36-49\%, respectively, lower than that of the CTM models. It is mostly related to the fact that CTM models are known to underestimate the organic fraction of $\mathrm{PM}_{10}$, in particular Secondary Organic Aerosols (SOA) by an order of magnitude (Bessagnet et al., 2008), therefore mass closure of $\mathrm{PM}_{10}$ could be significantly affected. Nevertheless, when dealing with ambient concentrations, modeled secondary inorganic aerosols of $9.4 \mu \mathrm{g} \mathrm{m}^{-3}$ for the winter of 2010 are comparable to the measured values of $8.2 \mu \mathrm{g} \mathrm{m}^{-3}$ for the winter of 2011 in Lens (Waked et al., 2014).

Regarding the results obtained, both approaches, the receptor-based models (CF and PSCF) as well as the deterministic CTM, exhibited similar conclusions for the geographical so urce areas of $\mathrm{PM}_{10}$ concentrations impacting HdF. On one hand, the receptor-based models are based on simplified hypotheses that do not take into account chemical reactivity and dry deposition during transport, but have the advantage of using real measurement data. This approach gives valuable information on the localization of potential impacting source areas with a qualitative estimation of their contribution, but no chemical speciation was available during this study. On the other hand, the deterministic CTM provides a quantitative estimation of the contribution of the different emission regions as well as chemical speciation. However, it depends strongly on the quality of the input data, in particular, the comprehensiveness and accuracy of the emission inventory which could be associated to significant uncertainties for some sources as well as the performance of the physico-chemical mechanisms. The good agreement obtained by both independent approaches increases the level of confidence to the findings of this study. Also, we demonstrated the synergy of both strategies. Indeed, the trajectory-based receptor study gives at first useful qualitative information about the localization of potential source areas that help to 
set-up, in a second step, efficient CTM quantitative modeling studies.

The results obtained from this work showed also that background pollution levels were not explained only by the three regions studied using the CTM approach. Thus, it will be necessary to also estimate the contributions of other less distant anthropogenic emission areas, such as Paris or HdF itself in order to highlight a possible influence of nearest emission sources. Indeed, the results of CF and PSCF applied to short-range BTs over a distance of $500 \mathrm{~km}$ from the receptor sites highlighted the existence of impacting sub-areas such as Paris, cities characterized with high population densities in northern France and Southern Belgium as well as marked seasonal influence for some regions which could be linked to specific activities such as biomass burning, road traffic as well as agricultural activities. From the CTM approach, an influence of the Paris area is shown to affect the south of HdF whereas an influence from the Lille metropolitan area is shown also to have an impact on the north of HdF in agreement with the results obtained for the CF/PSCF modeling results. Consequently, it will be interesting to detail these sub-areas by CTM to better evaluate their contributions. Therefore, this work shows how receptor-based models can effectively help to orientate further CTM studies.

\section{Acknowledgements}

The authors thank the CPER Climibio (Contrat plan État-Région), funded by the Région Hauts-de-France, the DREAL Hauts-de-France and the Ministère de l'Enseigne ment Supérieur et de la Recherche; The CaPPA project (Chemical and Physical Properties of the Atmosphere) funded by the French National Research Agency (ANR) through the PIA (Programme d'Investissement d'Avenir) under contract ANR-11-LABX-0005-01 and by the Regional Council, Hauts-de-France, and the European Funds for Regional Economic Development (FEDER); the 
Institut Pierre-Simon Laplace, Ecole Polytechnique, INERIS, CNRS, for developing the CHIMERE Chemistry Transport Model; Tiphaine Delaunay and Sandra Vermeesch of Atmo Hauts-de-France for providing pollutants data; the NOAA Air Resources Laboratory (ARL) for the provision of the HYSPLIT transport and dispersion model; the European Environment Agency, the University of Wyoming and the European Monitoring and Evaluation Program (EMEP) for meteorological and air quality data available in their databases and the research institutes which provide these data. 


\section{References}

Andersson, E., Kahnert, M., 2016. Coupling aerosol optics to the MATCH (v5.5.0) chemical transport model and the SALSA (v1) aerosol microphysics module. Geoscientific Model Development 9, 1803-1826.

Atmo-HdF, 2010. Programme de surveillance de la qualité de l'air en Nord-Pas de Calais. rapport d'étude 05/2010/TD.A.

Atmo-HdF, 2017. Bilan de la qualité de l'air en région Hauts de France. Atmo Hauts de France.

Beekmann, M., Prvôt, A., Drewnick, F., Sciare, J., Pand is, S. N., van der Gon, H. A. C. D., Crippa, M., Freutel, F., Poulain, L., Ghersi, V., Rodriguez, E., Beirle, S., Zotter, P., von der Weiden-Reinmüller, S. L., Bressi, M., Fountoukis, C., Petetin, H., Szidat, S., Schneider, J., Rosso, A., Haddad, I. E., Megaritis, A., Zhang, Q. J., Michoud, V., Slowik, J. G., Moukhtar, S., Kolmonen, P., Stohl, A., Eckhardt, S., Borbon, A., Gros, V., Marchand, N., Jaffrezo, J. L., Schwarzenboeck, A., Colomb, A., Wiedensohler, A., Borrmann, S., Lawrence, M., Baklanov, A., Baltensperger, U., 2015. In situ, satellite measurement and model evidence on the dominant regional contribution to fine particulate matter levels in the Paris megacity. Atmospheric Chemistry and Physics 15, 9577-9591.

Begum, B. A., Kim, E., Jeong, C. H., Lee, D. W., Hopke, P. K., 2005. Evaluation of the potential source contribution function using the 2002 Quebec forest fire episode. Atmospheric Environment 39, 3719-3724.

Bessagnet, B., Hodzic, A., Blanchard, O., Lattuati, M., Lebihan, O., Marfaing, H., Rouil, L., 2005. Origin of particulate matter pollution episodes in wintertime over the Paris basin. Atmospheric Environment 39, 6159-6174.

Bessagnet, B., Hodzic, A., Vautard, R., Beekmann, M., Cheinet, S., Honore, C., Liousse, C., 
Rouil, L., 2004. Aerosol modeling with chimere-preliminary evaluation at the continental scale. Atmospheric Environment 38, 2803-2817.

Bessagnet, B., Menut, L., Curci, G., Hodzic, A., Guillaume, B., Liousse, C., Moukhtar, S., Pun, B., Seigneur, C., Schulz, M., 2008. Regional modeling of carbonaceous aerosols over Europe-focus on secondary organic aerosols. Journal of Atmospheric Chemistry 61, 175-202.

Bihan, O. L., Mathe, F., Chambre, C., Bruno, P., Marfaing, H., 2006. Demonstration of equivalence of PM automated monitoring methods: results of the 1st measurement campaign on a parisian urban background air quality station, in: Conference on Air pollution and environmental health from science to action: the challenge of particulate matter, September 2006, Lille, France, pp. 104-105.

Boucher, O., Randall, D., Artaxo, P., Bretherton, C., Feingold, G., Forster, P., Kerminen, V.M., Kondo, Y., Liao, H., Lohmann, U., Rasch, P., Satheesh, S., Sherwood, S., Stevens, B., Zhang, X., 2013. Clouds and Aerosols. In: Climate Change 2013: The Physical Science Basis. Cambridge University Press, Cambridge, United Kingdom and New York, NY, USA. chapter Contribution of Working Group I to the Fifth Assessment Report of the Intergovernmental Panel on Climate Change.

Boylan, J., Russell, A., 2006. Pm and light extinction model performance metrics, goals, and criteria for three-dimensional air quality models. Atmospheric Environment 40, 4946-4959.

Bressi, M., Sciare, J., Ghersi, V., Mihalopoulos, N., Petit, J. E., Nicolas, J. B., Moukhtar, S., Rosso, A., Féron, A., Bonnaire, N., Poulakis, E., Theodosi, C., 2014. Sources and geographical origins of fine aerosols in Paris (France). Atmospheric Che mistry and Physics 14, 8813-8839.

CAMS, 2016. Regional Production, Description of the operational models and of the ENSEMBLE system. CAMS502015SC1. Copernicus Atmosphere Monitoring Service. 
Charron, A., Degrendele, C., Laongsri, B., Harrison, R. M., 2013. Receptor modelling of secondary and carbonaceous particulate matter at a southern UK site. Atmospheric Chemistry and Physics 13, 1879-1894.

Charron, A., Plaisance, H., Sauvage, S., Coddeville, P., Galloo, J. C., Guillermo, R., 1998. Intercomparison between three receptor-oriented models applied to acidic species in precipitation. Sci. Total Environ. 223, 53-63.

Cheng, M. D., Hopke, P. K., Barrie, L., Rippe, A., Olson, M., Landsberger, S., 1993. Qualitative determination of source regions of aerosol in Canadian high Arctic. Environ. Sci. Technol. 27, 2063-2071.

EEA, 2017. Air Quality e-Reporting Database. https://www.eea.europa.eu/data-and maps/data/aqereporting- 2 .

von Engeln, A., Teixeira, J., 2013. A planetary boundary layer height climatology derived from ECMWF reanalysis data. Journal of Climate 26, 6575-6590.

Favez, O., Petit, J. E., Bessagnet, B., Meleux, F., Chiappini, L., Lemeur, S., Labartette, C., Chappaz, C., Guergnion, P. Y., Saison, J. Y., Chretien, E., Pallares, C., Verlhac, S., Aujay, R., Malherbe, L., Beauchamp, M., Piot, C., Jaffrezo, J. L., Besombes, J. L., Sciare, J., Rouil, L., Leoz-Garziandia, E., 2012. Main properties and origins of winter PM10 pollution events in France. Pollut. Atmos. Clim. Santé Société, 163-181.

Gao, N., Cheng, M. D., Hopke, P. K., 1993. Potential source contribution function analysis and source apportionment of sulfur species measured at Rubidoux, CA during the southern California air quality study, 1987. Anal. Chim. Acta 277, 369-380.

Guenther, A., Karl, T., Harley, P., Wiedinmyer, C., Palmer, P. I., Geron, C., 2006. Estimates of global terrestrial isoprene emissions using MEGAN (Model of Emissions of Gases and 
Aerosols from Nature). Atmospheric Chemistry and Physics 6, 3181-3210.

Guerreiro, C. B. B., Foltescu, V., de Leeuw, F., 2014. Air quality status and trends in Europe. Atmospheric Environment 98, 376-384.

Hafner, W. D., Hites, R. A., 2003. Potential sources of pesticides, pcbs, and pahs to the atmosphere of the great lakes. Environ. Sci. Technol. 37, 3764-3773.

Hauglustaine, D. A., Balkanski, Y., Schulz, M., 2014. A global model simulation of present and future nitrate aerosols and their direct radiative forcing of climate. Atmospheric Chemistry and Physics 14, 11031-11063.

Im, U., Bianconi, R., Solazzo, E., Kioutsioukis, I., co authors, 2015. Evaluation of operational online-coupled regional air quality models over Europe and North America in the context of AQMEII phase 2. part 2: Particulate matter. Atmospheric Environment 115, 421-441.

Janssens-Maenhout, G., Dentener, F., van Aardenne, J., Monni, S., Pagliari, V., Orlandini, L., Klimont, Z., Kurokawa, J., Akimoto, H., Ohara, T., Wankmüller, R., Battye, B., Grano, D., Zuber, A., Keating, T., 2012. EDGAR-HTAP: a harmonized gridded air pollution emission dataset based on national inventories. JRC technical and Scientific report, EUR 25229 ISBN 978-92-79-23123-0.

Kim, S., Hong, K. H., Jun, H., Park, Y. J., Park, M., Sunwoo, Y., 2014. Effect of precipitation on air pollutant concentration in Seoul, Korea. Asian Journal of Atmospheric Environment 8, 202-2011.

Kiss, G., Imre, K., Molnar, A., Gelencser, A., 2017. Bias caused by water adsorption in hourly pm measurements. Atmos. Meas. Tech. 10, 2477-2484.

Li, M., Huang, X., Zhu, L., Li, J., Song, Y., Cai, X., Xie, S., 2012. Analysis of the transport pathways and potential sources of PM10 in Shanghai based on three methods. Sci. Total 
Environ 414, 525-534.

Memmesheimer, M., Friese, E., Ebel, A., Jakobs, H., Feld mann, H., Kessler, C., Piekorz, G., 2004. Long-term simulations of particulate matter in Europe on different scales using sequential nesting of a regional model. International Journal of Environment and Pollution 22, 108-132.

Menut, L., Bessagnet, B., Khvorostyanov, D., Beekmann, M., Blond, N., Colette, A., Coll, I., Curci, G., Foret, G., Hodzic, A., Mailler, S., Meleux, F., Monge, J. L., Pison, I., Siour, G., Turquety, S., Valari, M., Vautard, R., Vivanco, M. G., 2013. Chimere 2013: a model for regional atmospheric composition modelling. Geosci. Model Dev. 6, 981-1028.

Oliveira, D., 2017. Identification of the main sources and geographical origins of PM10 in the northern part of France. Doctoral dissertation, University of Lille, 346 pages. Available at https://www.theses.fr/201433516.

Pay, M. T., Jiménez-Guerrero, P., Baldasano, J. M., 2012. Assessing sensitivity regimes of secondary inorganic aerosol formation in Europe with the CALIOPE-EU modeling system. Atmospheric Environment 51, 146-164.

Petit, J. E., Amodeo, T., Meleux, F., Bessagnet, B., Menut, L., Grenier, D., Pellan, Y., Ockler, A., Rocq, B., Gros, V., Sciare, J., Favez, O., 2017a. Characterising an intense PM pollution episode in March 2015 in France from multi-site approach and near real time data: Climatology, variabilities, geographical origins and model evaluation. Atmospheric Environment 155, 68-84.

Petit, J. E., Favez, O., Albinet, A., Canonaco, F., 2017b. A user-friendly tool for comprehensive evaluation of the geographical origins of atmospheric pollution: Wind and trajectory analyses. Environ. Model. Softw. 88, 183-187.

Polissar, A. V., Hopke, P. K., Harris, J. M., 2001. Source regions for atmospheric aerosol 
measured at Barrow, Alaska. Environ. Sci. Technol. 35, 4214-4226.

Pongkiatkul, P., Oanh, N. T. K., 2007. Assessment of potential long-range transport of particulate air pollution using trajectory modeling and monitoring data. Atmospheric Research 85, 3-17. Putaud, J. P., Dingenen, R. V., Alastuey, A., Bauer, H., Birmili, W., J.Cyrys, Flentje, H., Fuzzi, S., Gehrig, R., Hansson, H. C., Harrison, R. M., Herrmann, H., Hitzenberger, R., Hglin, C., Jones, A. M., Kasper-Giebl, A., Kiss, G., Kousa, A., Kuhlbusch, T. A. J., Lschau, G., Maenhaut, W., Molnar, A., Moreno, T., Pekkanen, J., Perrino, C., Pitz, M., Puxbaum, H., Querol, X., Rodriguez, S., Salma, I., Schwarz, J., Smolik, J., Schneider, J., Spindler, G., ten Brink, H., Tursic, J., Viana, M., Wiedensohler, A., Raes, F., 2010. A European aerosol phenomenology 3: Physical and chemical characteristics of particulate matter from 60 rural, urban, and kerbside sites across Europe. Atmospheric Environment 44, 1308-1320.

Putaud, J. P., Raes, F., Dingenen, R. V., coauthors, 2004. A european aerosol phenomenology-2: chemical characteristics of particulate matter at kerbside, urban, rural and background sites in Europe. Atmospheric Environment 38, 2579-2595.

Rea, G., Turquety, S., Menut, L., Briant, R., Mailler, S., 2015, G. S., 2015. Source contributions to 2012 summertime aerosols in the Euro-Mediterranean region. Atmospheric Chemistry and Physics 15, 8013-8036.

Schaap, M., Timmermans, R. M. A., Roemer, M. G. M., Boersen, G. A. C., 2008. The Lotos-Euros Model: Description, Validation and Latest Developments. http://resolver.tudelft.n1/uuid:9965acf1-93d3-415b-be60-157586621328.

Seibert, P., Kromp-Kolb, H., Baltensperger, U., Jost, D. T., Schwikowski, M., 1994. Trajectory Analysis of High-Alpine Air Pollution Data. Air Pollution Modeling and Its Application, Springer. 
Sic, B., Amraoui, L. E., Marécal, V., Josse, B., Arteta, J., Guth, J., Joly, M., Hamer, P. D., 2015. Modelling of primary aerosols in the chemical transport model MOCAGE: development and evaluation of aerosol physical parameterizations. Geoscientific Model Development 8, $381-408$.

Simpson, D., Benedictow, A., Berge, H., Bergström, R., Emberson, L. D., Fagerli, H., Flechard, C. R., Hayman, G. D., Gauss, M., Jonson, J. E., Jenkin, M. E., Nyri, A., Richter, C., Semeena, V. S., Tsyro, S., Tuovinen, J.P., Valdebenito, ., Wind, P., 2012. The EMEP MSC-W chemical transport model - technical description. Atmospheric Chemistry and Physics 16, 7825-7865.

Skamarock, W. C., Klemp, J. B., Dudhia, J., Gill, D. O., Barker, D. M., Duda, M. G., Huang, X. Y., Wang, W., Powers, J. G., 2008. A description of the advanced research WRF version 3. Technical Report. NCAR technical note.

Sofiev, M., Vira, J., Kouznetsov, R., Prank, M., Soares, J., Genikhovich, E., 2015. Construction of the SILAM eulerian atmospheric dispersion model based on the advection algorithm of Michael Galperin. Geoscientific Model Development 8, 3497-3522.

Stein, A. F., Draxler, R. R., Rolph, G. D., Stunder, B. J. B., Cohen, M. D., Ngan, F., 2015. Noaas hysplit atmospheric transport and dispersion modeling system. Bulletin of the American Meteorological Society 96, 2059-2077.

Stohl, A., 1998. Computation, accuracy and applications of trajectories - a review and bibliography. Atmospheric Environment 32, 947-966.

Verlac, S., 2017. Suivi d'équivalence des analyseurs automatiques de PM10 et PM2.5 - Bilan 2013-2016. report LCSQA, DRC-17-159622-00730A.

Vieno, M., Heal, M. R., Twigg, M. M., MacKenzie, I. A., Braban, C. F., Lingard, J. J. N., Ritchie, S., Beck, R. C., Moring, A., Ots, R., Marco, C. F. D., Nemitz, E., Sutton, M. A., Reis, S., 2016. 
The UK particulate matter air pollution episode of March-April 2014: More than Saharan dust. Environmental Research Letters 11.

Waked, A., Bourin, A., Michoud, V., Perdrix, E., Alleman, L. Y., Sauvage, S., Delaunay, T., Vermeech, S., Petit, J.E., Riffault, V., 2018. Investigation of the geographical origins of pm10 based on long, medium and short-range air mass back-trajectories impacting northern france during the period 20092013. Atmospheric Environment 193, 143-152.

Waked, A., Favez, O., Alleman, L. Y., Piot, C., Petit, J. E., Delaunay, T., Verlinden, E., Golly, B., Besombes, J. L., Jaffrezo, J. L., Leoz-Garziandia, E., 2014. Source apportionment of PM10 in a north-western Europe regional urban background site (Lens, france) using positive matrix factorization and including primary biogenic emissions. Atmospheric Chemistry and Physics $14,3325-3346$.

WHO, 2003. Health aspects of air pollution with particulate matter, ozone and nitrogen dioxide: report on a WHO working group, Bonn, Germany. http:/apps.who.int/iris/handle/10665/107478.

Xie, Y., Berkowitz, C. M., 2007. The use of conditional probability functions and potential source contribution functions to identify source regions and advection pathways of hydrocarbon emissions in Houston, Texas. Atmospheric Environment 41, 5831-5847.

Zeng, Y., Hopke, P. K., 1989. A study of the sources of acid precipiation in Ontario, Canada. Atmospheric Environment 7, 1499-1509.

Zhang, Y., Sartelet, K., Wu, S. Y., Seigneur, C., 2013. Application of WRF/Chem-MADRID and WRF-Polyphemus in Europe - part 1: Model description, evaluation of meteorological predictions, and aerosol-meteorology interactions. Atmospheric Chemistry and Physics 13, 6807-6843. 
Figure 1: a) Map of the domain considered for the CHIMERECTM simulations with colored areas referring to the Hauts-de-France region (HdF; in yellow) and to anthropogenic emissions from the British Isles (in red), the Near East (in green) and the Far East (in blue). b) Location of the 12 receptor sites considered for the trajectory-based models CF/PSCF in HdF (indicated by black dots)

Figure 2: Map of the surface measurements stations used for validation of the CHIMERE CTM simulations: $\mathrm{PM}_{10}$ concentrations (green dots) and meteorological parameters : wind/temperature (red dots), precipitations (blue dots)

Figure 3: Maps showing the geographical location of potential $\mathrm{PM}_{10}$ source areas having impacted HdF receptor sites in 2010 obtained by: (left) Concentration Field (CF) for the whole year; (right) Potential Source Contribution Function (PSCF) only for the highest PM ${ }_{10}$ concentrations (tri-hourly averages $\geq 40 \mu \mathrm{g} \mathrm{m}^{-3}$ ). All maps take into account the Cut-offs for Rain and Altitude (CRA). From top to bottom, maps showing long-range sources (CRA), maps using a weighting function $(\mathrm{CRA}+\mathrm{WF})$ showing medium-range sources and maps of short-range sources (ST) with and without WF (respectively for infrequent or frequent air mass origins).

Figure 4: Seasonal maps of the geographical location of potential source areas of $\mathrm{PM}_{10}$ impacting HdF for all days of year 2010 using the CF model (top rows) and for the highest $\mathrm{PM}_{10}$ concentrations only using the PSCF model (bottom rows), for long and medium-range trajectories (respectively without or with weighting function, WF), taking into account the Cut-offs for Rain and Altitude (CRA). 
Figure 5: Seasonal maps of the geographical location of potential source areas of $\mathrm{PM}_{10}$ impacting HdF for all days of year 2010 using the CF method (top rows) and for the highest concentrations only using the PSCF method (bottom rows) for short-range trajectories with or without WF (respectively for infrequent of frequent air mass origins) taking into account the Cut-offs for Rain and Altitude (CRA) 
Figure 6: Statistics on $\mathrm{PM}_{10}$ surface concentrations modeled by CTM on the 2 departments of $\mathrm{HdF}$ : mean, standard deviation, maximum and number of hours with concentration over $25 \mu \mathrm{gm}$ $-3$.

Figure 7: Map of seasonal averaged contributions of the 3 selected areas (BI, Near-East, Far-East) to $\mathrm{PM}_{10}$ surface concentrations modeled by CTM on the 2 departments of $\mathrm{HdF}$.

Figure 8: Map of seasonal averaged contributions of the 3 tested areas (BI, Near-East, Far-East) to $\mathrm{PM}_{10}$ surface concentrations modeled by CTM, on the 2 departments of HdF, in case of pollution events $\left(\mathrm{PM}_{10} \geq 25 \mu \mathrm{g} / \mathrm{m}^{3}\right)$

Figure 9: Seasonal means and annual mean of surface $\mathrm{PM}_{10}$ chemical speciation modeled by CTM for the (a) reference simulation and for the simulation without (b) BI and (c) Near-East anthropogenic emissions 
Table 1: Monthly Limit Altitudes (MLA) above which backward-trajectories endpoints were removed (from von Engeln and Teixeira (2013)).

\begin{tabular}{|c|c|}
\hline Month & Altitude (m) \\
\hline January & 1000 \\
March & 1100 \\
April & 1600 \\
May & 1600 \\
June & 2000 \\
July & 1800 \\
August & 1800 \\
September & 1500 \\
October & 1000 \\
November & 800 \\
December & 800 \\
\hline
\end{tabular}


Table 2: Specific characteristics of the CHIMERE simulation

\begin{tabular}{|c|c|c|c|}
\hline & $\begin{array}{c}\text { Area where } \\
\text { anthropogenic } \\
\text { emissions were not } \\
\text { Simulations }\end{array}$ & & \\
taken into account & Domain area & Anthropogenic \\
emissions
\end{tabular}


Table 3: WRF validation with statistics, on modeled and observed temperature (T), zonal (U) and meridional (V) wind speeds and precipitation $(\mathrm{P})$. Modeled and observed means $(\mu)$, standard deviation $(\sigma)$, correlation coefficient (r) and root mean square error (RMSE).

\begin{tabular}{|c|c|c|c|c|c|}
\hline & & $\mu_{\text {mod }} \pm \sigma_{\text {mod }}$ & $\mu_{o b s} \pm \sigma_{o b s}$ & $\mathrm{r}$ & RMSE \\
\hline \multirow{4}{*}{ Winter } & $\mathrm{T}\left({ }^{\circ} \mathrm{C}\right)$ & $-0.23 \pm 4.72$ & $-0.46 \pm 4.41$ & 0.83 & 2.75 \\
\hline & $\mathrm{U}(\mathrm{m} / \mathrm{s})$ & $0.49 \pm 5.11$ & $0.02 \pm 3.33$ & 0.78 & 3.30 \\
\hline & $\mathrm{V}(\mathrm{m} / \mathrm{s})$ & $0.16 \pm 4.52$ & $0.14 \pm 3.15$ & 0.78 & 2.89 \\
\hline & $\mathrm{P}(\mathrm{mm} / \mathrm{day})$ & $3.63 \pm 5.93$ & $2.81 \pm 5.38$ & 0.56 & 5.36 \\
\hline \multirow{4}{*}{ Spring } & $\mathrm{T}\left({ }^{o} \mathrm{C}\right)$ & $9.39 \pm 5.23$ & $8.86 \pm 5.63$ & 0.91 & 2.36 \\
\hline & $\mathrm{U}(\mathrm{m} / \mathrm{s})$ & $1.20 \pm 4.52$ & $0.68 \pm 3.24$ & 0.79 & 2.83 \\
\hline & $\mathrm{V}(\mathrm{m} / \mathrm{s})$ & $-0.73 \pm 4.46$ & $-0.44 \pm 3.10$ & 0.79 & 2.81 \\
\hline & $\mathrm{P}(\mathrm{mm} / \mathrm{day})$ & $1.88 \pm 4.12$ & $2.32 \pm 4.98$ & 0.31 & 5.40 \\
\hline \multirow{4}{*}{ Summer } & $\mathrm{T}\left({ }^{o} \mathrm{C}\right)$ & $17.3 \pm 6.18$ & $18.2 \pm 5.07$ & 0.87 & 3.14 \\
\hline & $\mathrm{U}(\mathrm{m} / \mathrm{s})$ & $1.81 \pm 3.77$ & $1.20 \pm 2.73$ & 0.72 & 2.72 \\
\hline & $\mathrm{V}(\mathrm{m} / \mathrm{s})$ & $-0.58 \pm 3.57$ & $-0.10 \pm 2.65$ & 0.70 & 2.64 \\
\hline & $\mathrm{P}(\mathrm{mm} / \mathrm{day})$ & $1.29 \pm 4.42$ & $2.85 \pm 7.14$ & 0.35 & 7.14 \\
\hline \multirow{4}{*}{ Fall } & $\mathrm{T}\left({ }^{\circ} \mathrm{C}\right)$ & $9.17 \pm 4.76$ & $10.1 \pm 5.06$ & 0.89 & 2.44 \\
\hline & $\mathrm{U}(\mathrm{m} / \mathrm{s})$ & $1.38 \pm 4.69$ & $0.64 \pm 3.34$ & 0.82 & 2.82 \\
\hline & $\mathrm{V}(\mathrm{m} / \mathrm{s})$ & $0.95 \pm 4.15$ & $0.79 \pm 2.91$ & 0.76 & 2.72 \\
\hline & $\mathrm{P}(\mathrm{mm} / \mathrm{day})$ & $3.05 \pm 6.07$ & $2.95 \pm 6.28$ & 0.54 & 5.90 \\
\hline
\end{tabular}


Table 4: CHIMERE validation with statistics on modeled and observed $\mathrm{PM}_{10}$ concentrations.

Modeled and observed seasonal means $(\mu)$, standard deviation $(\sigma)$, correlation coefficient $(\mathrm{r})$, root mean square error (RMSE), mean fractional error (MFE) and mean fractional bias (MFB).

\begin{tabular}{|c|c|c|c|c|c|c|c|c|}
\hline Season & $\mu_{\text {mod }} \pm$ & $\mu_{o b s} \pm$ & $\mathrm{r}$ & RMSE $(\mu$ & MFE (\%) & MFB (\%) & Perf. Goal & Perf Crit. \\
& $\sigma_{\text {mod }}(\mu$ & $\sigma_{o b s}(\mu$ & & $\left.\mathrm{g} / \mathrm{m}^{3}\right)$ & & & & \\
& $\left.\mathrm{g} / \mathrm{m}^{3}\right)$ & $\left.\mathrm{g} / \mathrm{m}^{3}\right)$ & & & & & & \\
\hline Winter & $14.1 \pm$ & $24.5 \pm$ & 0.49 & 19.6 & 58.0 & -35.7 & no & yes \\
& 7.8 & 19.1 & & & & & & yo \\
Spring & $10.7 \pm$ & $18.5 \pm$ & 0.44 & 12.3 & 57.4 & -43.6 & yes \\
Summer & $8.0 \pm 3.2$ & $15.6 \pm$ & 0.17 & 10.6 & 66.9 & -58.1 & no & yes \\
Fall & $11.8 \pm$ & $15.7 \pm$ & 0.35 & 10.3 & 53.0 & -19.5 & no & yes \\
& 6.2 & 9.7 & & & & & & \\
\hline
\end{tabular}


Table 5: Contributions of each selected area to modeled $\mathrm{PM}_{10}$ surface concentrations by CTM ( $\left\langle\overline{\Delta C^{\text {area }}}\right\rangle$ ), over $\mathrm{HdF}$, on annual basis and during pollution events ( $\geq 25 \mu \mathrm{g} / \mathrm{m}^{3}$ ); corresponding temporal standard deviations $\left(\sigma_{t}\right)$; annual mean of the spatial standard deviation over $\operatorname{HdF}\left(\sigma_{s}\right)$

\begin{tabular}{|c|c|c|c|}
\hline Area & $\overline{\left\langle\overline{\Delta C^{\text {area }}}\right\rangle \pm \sigma_{t}(\%)}$ & $\sigma_{s}(\%)$ & $\begin{array}{c}\left\langle\overline{\Delta C^{\text {area }}}\right\rangle \pm \sigma_{t}(\%) \\
\text { for pollution events } \geq \\
25 \mu \mathrm{g} / \mathrm{m}^{3}\end{array}$ \\
\hline $\mathrm{BI}$ & $17.1 \pm 21.8$ & 5.8 & $7.7 \pm 14.3$ \\
\hline Near-East & $17.5 \pm 24.4$ & 6.9 & $42.9 \pm 26.3$ \\
\hline Far-East & $1.3 \pm 4.3$ & 0.5 & $2.7 \pm 3.6$ \\
\hline
\end{tabular}


Table 6: Contributions of each selected area to modeled $\mathrm{PM}_{10}$ surface concentrations by CTM ( $\left\langle\overline{\Delta C^{\text {area }}}\right\rangle$ ), over HdF, on a seasonal basis.

\begin{tabular}{|c|c|c|c|c|}
\hline & \multicolumn{4}{|c|}{$\left\langle\overline{\Delta C^{\text {area }}}\right\rangle$} \\
\hline Area & Winter (\%) & Spring (\%) & Summer (\%) & Fall (\%) \\
\hline BI & 13.0 & 16.6 & 23.4 & 15.2 \\
Near-East & 18.8 & 25.2 & 11.1 & 14.9 \\
Far-East & 2.6 & 1.4 & 0.3 & 1.0 \\
\hline
\end{tabular}




\section{Highlights}

- The continental and regional sources of pollutants impacting northern France are identified and quantified.

- Two independent approaches, statistical sources-receptor and deterministic chemistry-transport models are used.

- Both approaches showed consistency, highlighting the influence of several areas on the northern France pollution. 


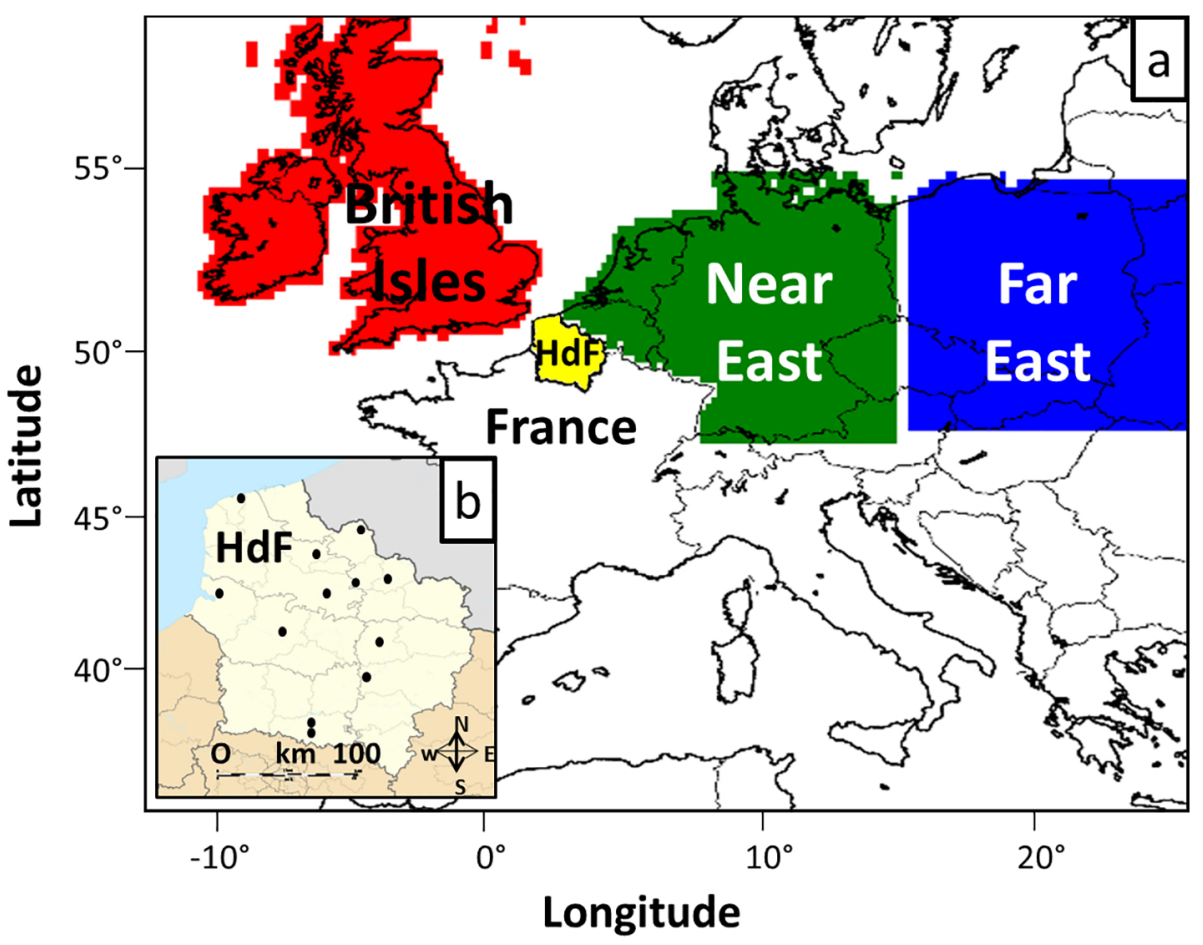

Figure 1 


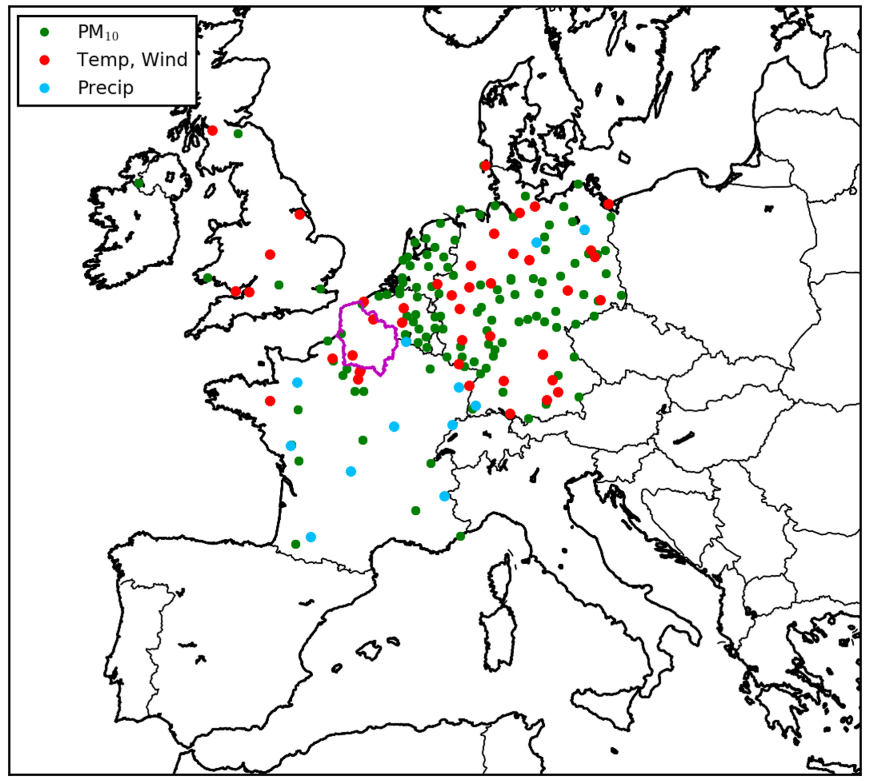

Figure 2 
CF (PM 10 concentrations)

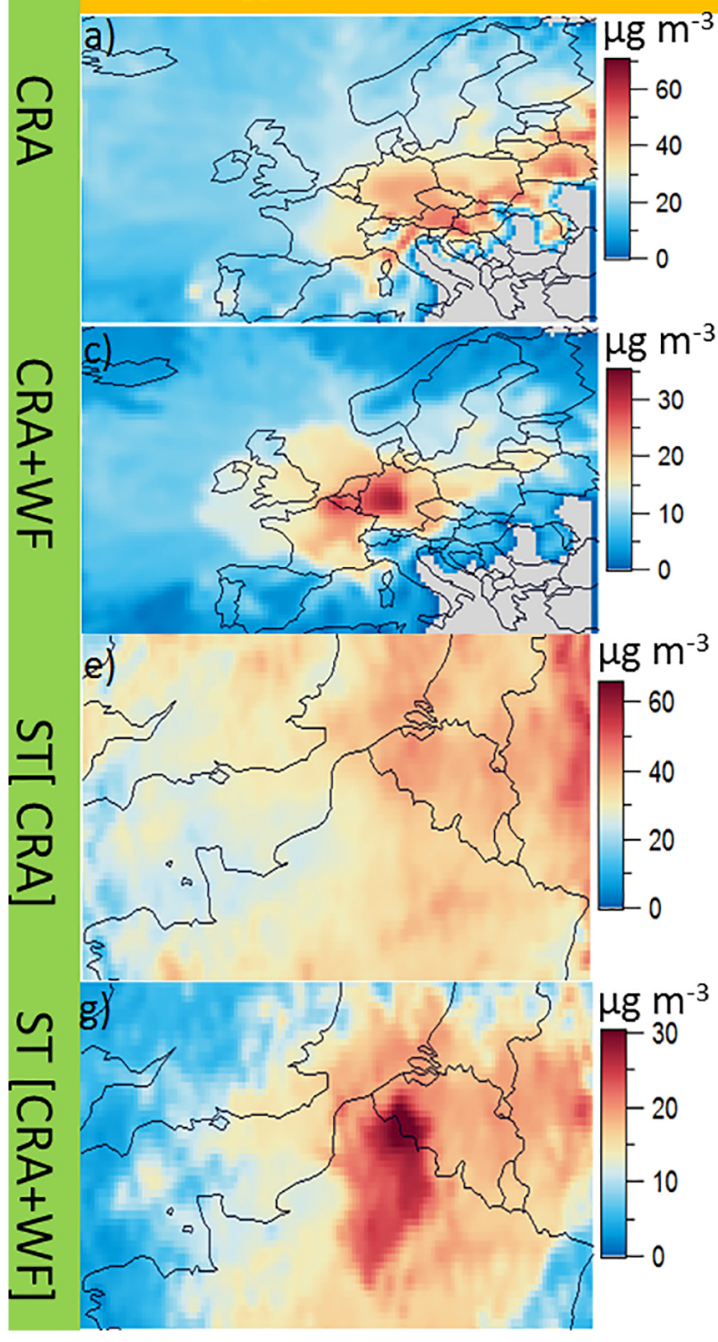

\section{PSCF (conditional probabilities)}

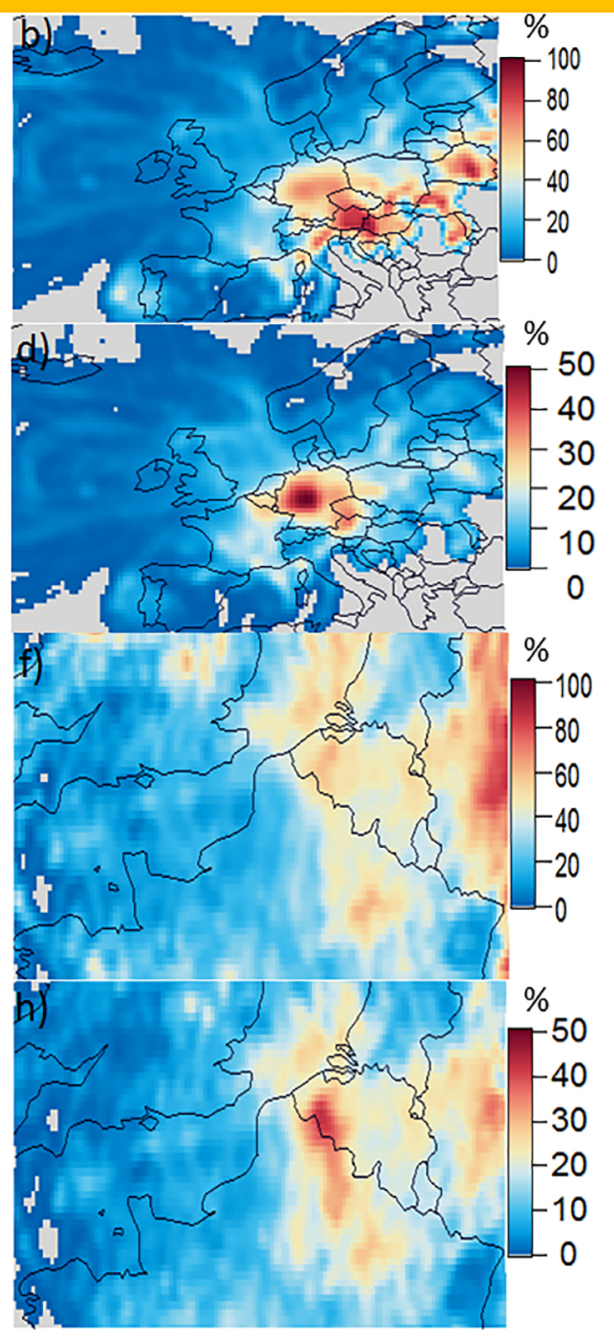

Figure 3 


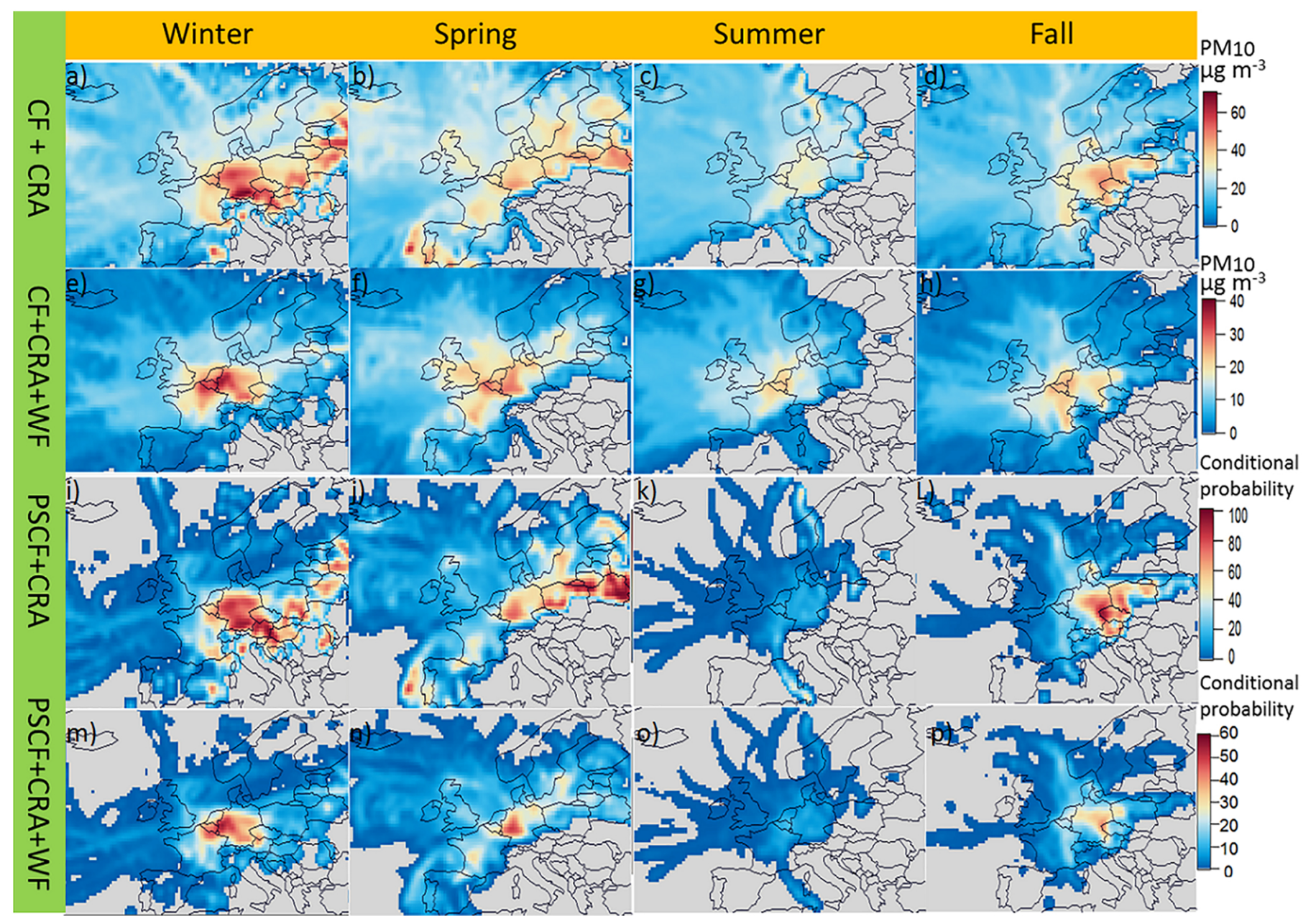

Figure 4 


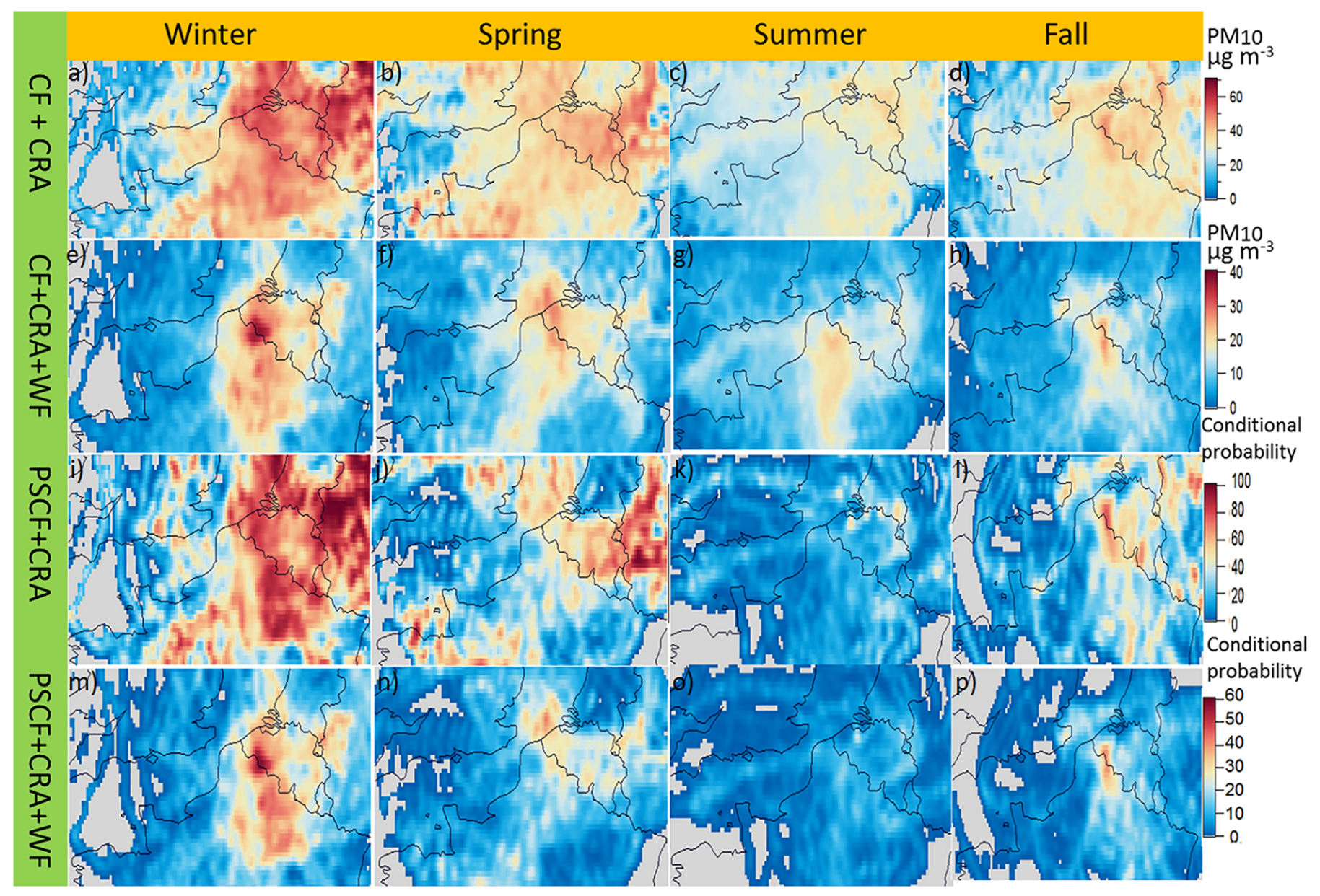

Figure 5 
Reference $\mathrm{PM}_{10}$ Concentration

Mean
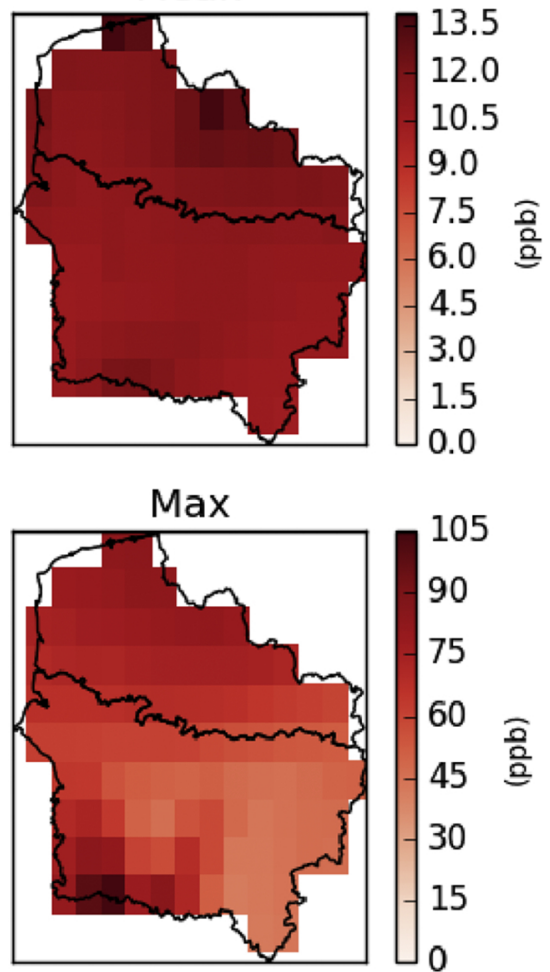

Std

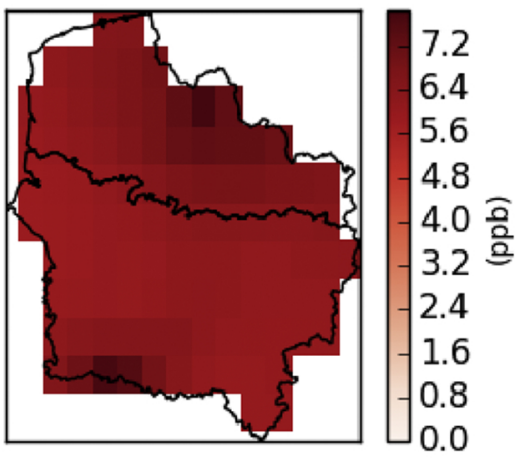

hours $>25 \mu \mathrm{g} / \mathrm{m}^{3}$

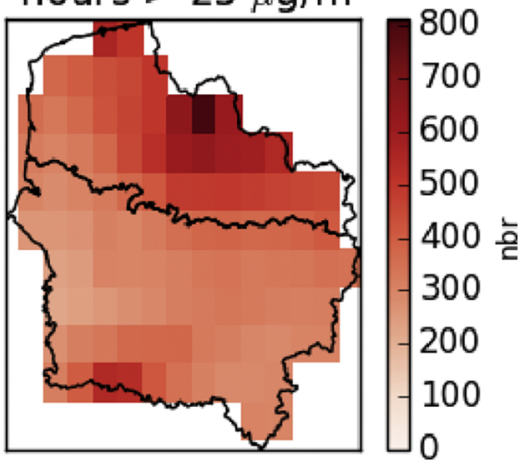

Figure 6 
Contributions to $\mathrm{PM}_{10}$ Concentrations

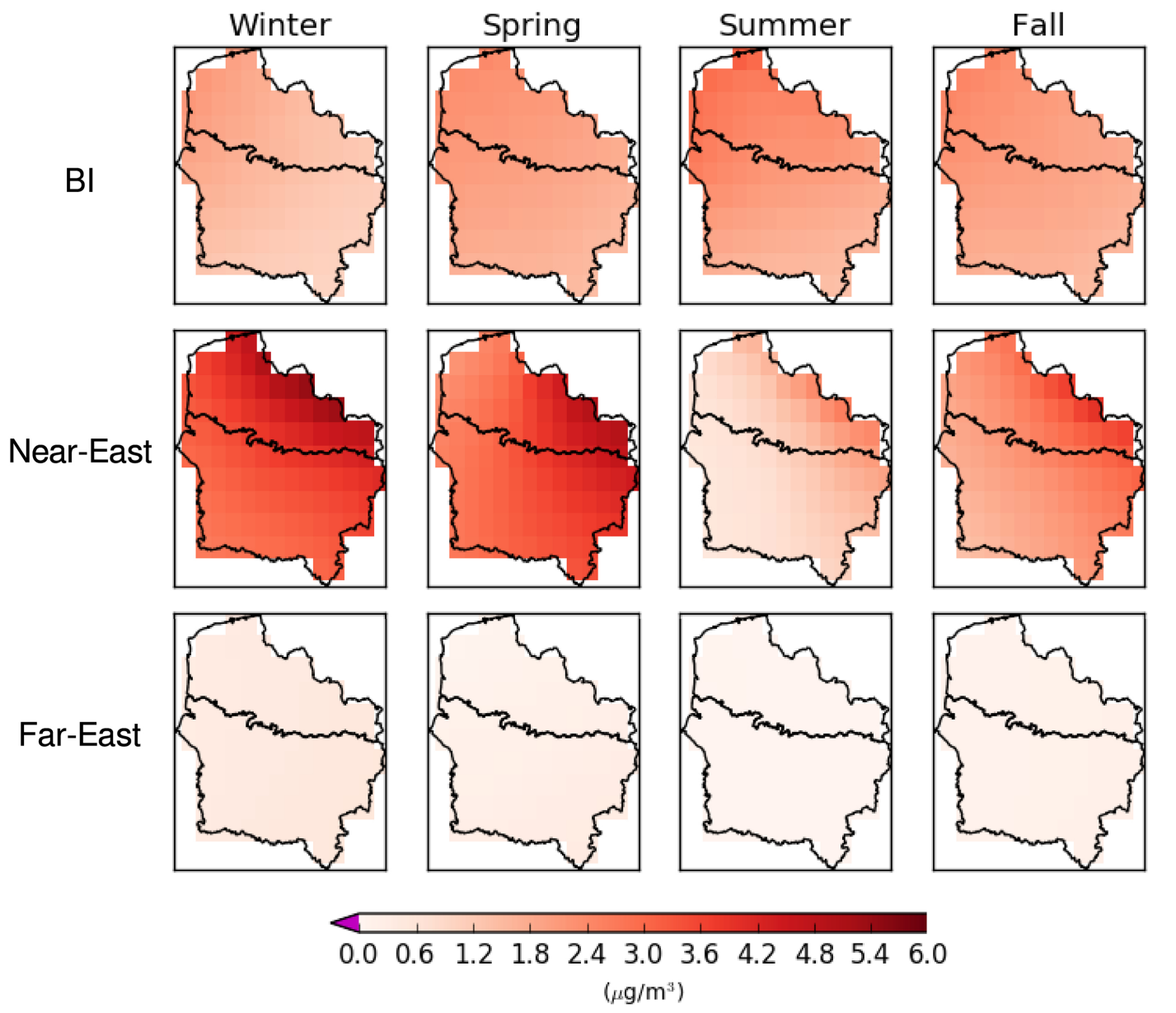

Figure 7 
Contributions to $\mathrm{PM}_{10}$ Concentrations during Pollution Events

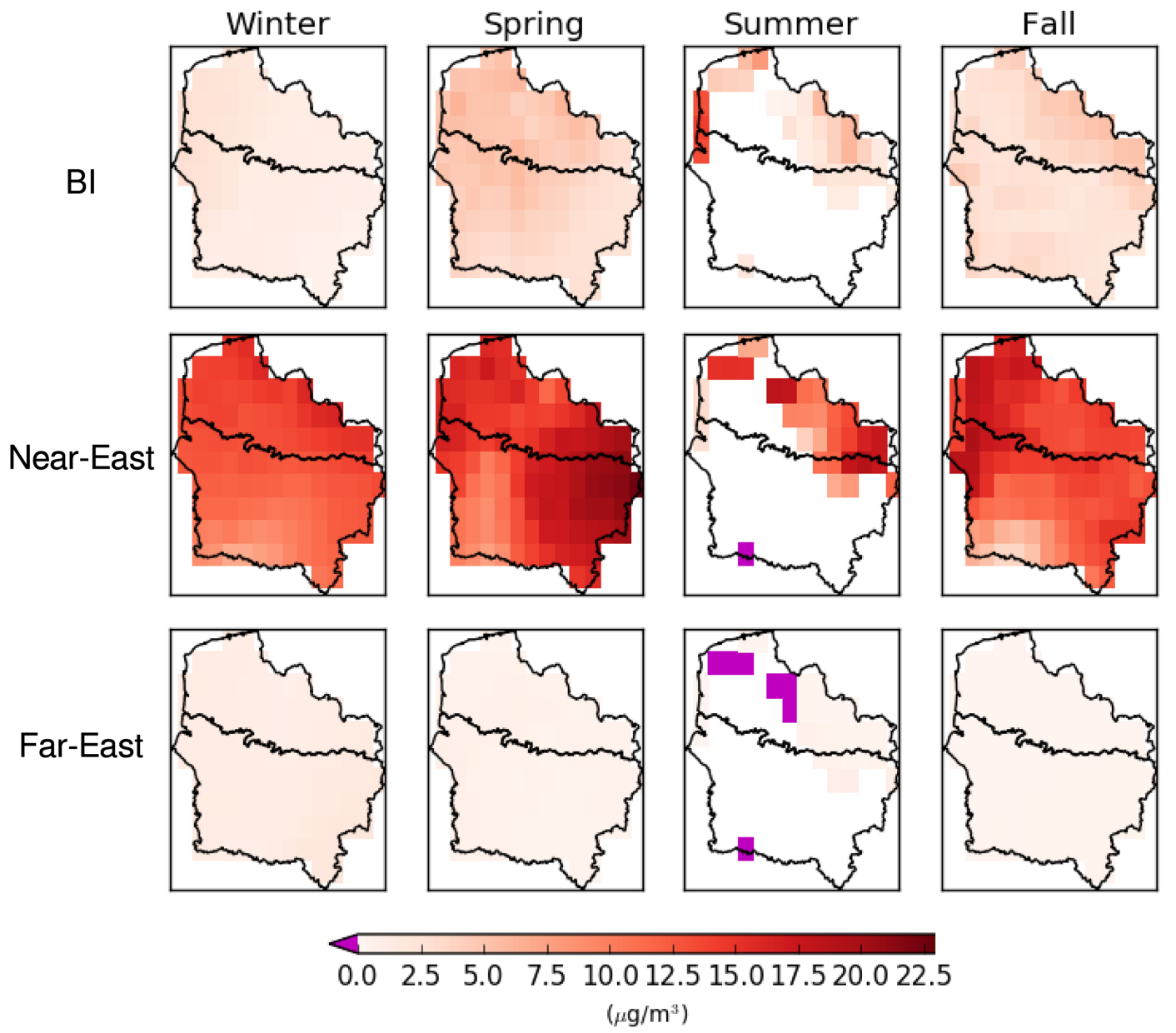

Figure 8 


\section{(a) Reference}

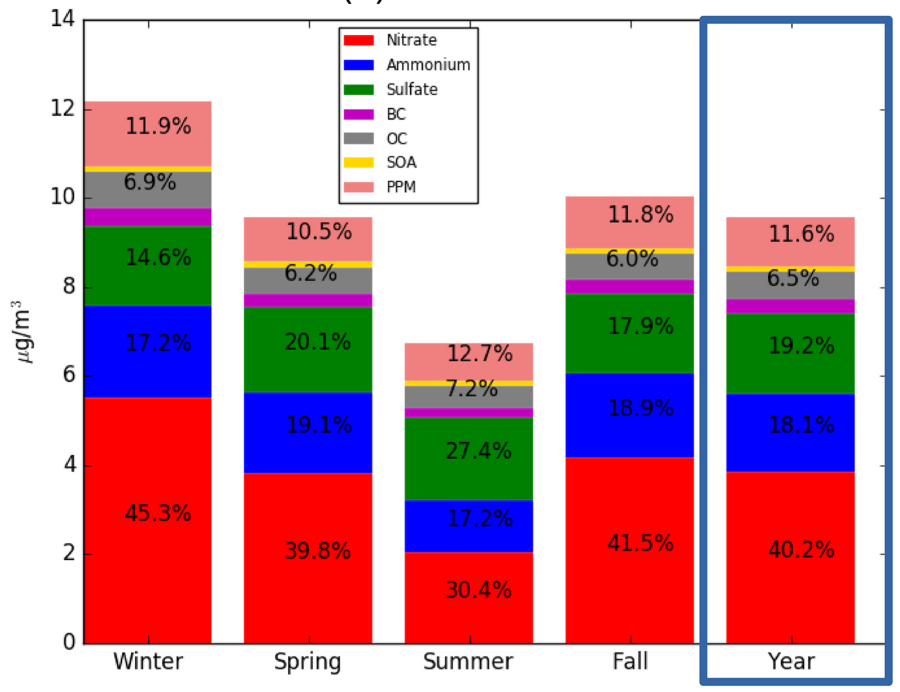

(b) Without $\mathrm{BI}$ anth. emissions

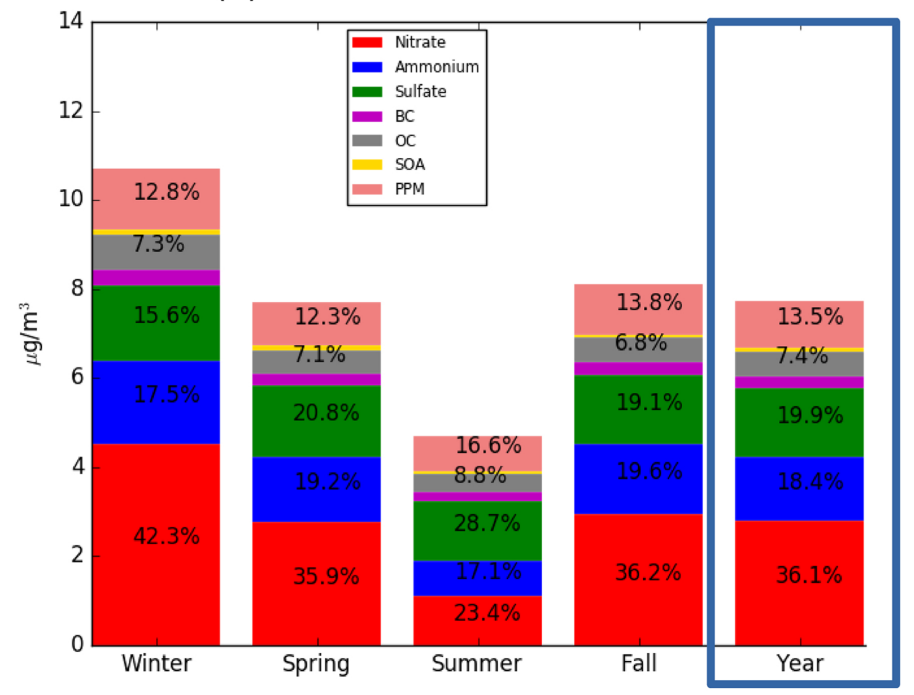

(c) Without Near-East anth. emissions

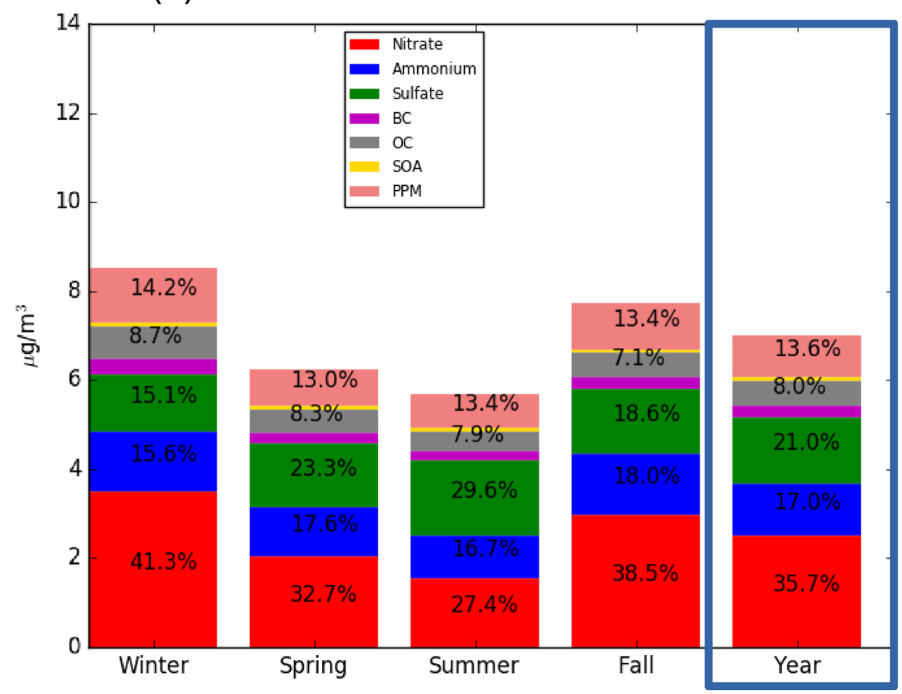

